\title{
Total Quality Management Practices and Corporate Green Performance: Does Organizational Culture Matter?
}

\author{
Muhammad Khuram Khalil *(D) and Umaporn Muneenam \\ Faculty of Environmental Management, Prince of Songkla University, Songkhla 90110, Thailand; \\ umaporn.m@psu.ac.th \\ * Correspondence: khuramkhali193@gmail.com; Tel.: +66-092-846-0172
}

Citation: Khalil, M.K.; Muneenam,

U. Total Quality Management

Practices and Corporate Green

Performance: Does Organizational

Culture Matter? Sustainability 2021

13, 11021. https://doi.org/

$10.3390 /$ su131911021

Academic Editors: Chunlu Liu and António Abreu

Received: 17 July 2021

Accepted: 29 September 2021

Published: 5 October 2021

Publisher's Note: MDPI stays neutral with regard to jurisdictional claims in published maps and institutional affiliations.

Copyright: (c) 2021 by the authors. Licensee MDPI, Basel, Switzerland. This article is an open access article distributed under the terms and conditions of the Creative Commons Attribution (CC BY) license (https:/ / creativecommons.org/licenses/by/ $4.0 /)$.

\begin{abstract}
Bearing in mind the environmental corrosion primarily triggered by the service sector, as well as the lack of studies detecting the factors that enable an organization to deal with this concern, the aim of this study is to analyze the impact of total quality management (TQM) practices on corporate green performance (CGP) and to investigate the causal relationship between total quality management practices and corporate green performance. This research also explores the mediating role of organizational culture (OC) within the relationship between TQM practices and CGP. In particular, this study is based on the MBNQA model, institutional theory, and green theory. The researchers collected data from 369 participants across 123 large and medium-sized private firms in the health sector in Pakistan. The structural analyses revealed the significant and positive impact of TQM practices on CGP. This demonstrates that TQM practices substantially augment organizational competencies to achieve green performance objectives. TQM practices have also had a positive and significant impression on organizational culture; furthermore, a parallel impact is seen between OC and CGP. Finally, OC is shown to have positively and significantly mediated the relationship between TQM and CGP. This study's contextual analysis suggests that TQM is an equally important factor in accomplishing CGP objectives for both large and medium-sized firms.
\end{abstract}

Keywords: corporate green performance; organizational culture; total quality management; private health sector; SmartPLS

\section{Introduction}

In modern times, businesses, especially the service sector, have begun to encounter increased pressure from various stakeholders to think about how their actions affect the natural environment and society [1]. Ecologists constantly struggle to raise public awareness of the decline in natural reserves [2]. The variation in the natural environment and the substantial intensification of air, land, and water pollution lead organizations to shift their dependence away from fossil fuels, which produce ecological concerns, and to take advantage of renewable resources [3-5]. Moreover, to enhance public awareness, provincial and international laws to save the natural environment also oblige firms to be concerned about how their activities affect the natural environment and to adopt green or environmentally friendly production processes [6,7]. According to Masocha [8], this situation has also altered stakeholders' preferences and needs, and urged them to choose the firm's products or services that cause the least harm to the natural environment. However, firms need to assure consumers that the standards of their services and goods will be high, and that their actions will not negatively affect the environment.

Firms can use green approaches to address concerns about the natural environment. Such activities are characterized by environmentally friendly practices that an organization can adopt in order to become a more sustainable organization. These businesses focus on reducing their impact on the environment through initiatives that reduce their unethical environmental practices by ensuring that corporate practices meet a minimum level of sustainability. Corporate green practices fluctuate from sector to sector, and are often 
unique to the type of firm and the product or service it provides [9]. The corporate green performance (CGP) concept centres on upgrading current practices or launching new products and practices [10] in such a way that it both fulfils the quality needs of stakeholders and results in improved environmental performance [11]. CGP is related to green management, green infrastructure, and procedures to lessen the environmental problems triggered by the organization's activities [4,12]. Another factor connected to CGP is green innovation, whereby an organization presents unique ideas that empower management to think and work for society and mitigate other environmental hazards. Nevertheless, according to Wang [13] and Zhang and Rong [14], CGP research is in the initial stage, and there is a strong need for literature to be enriched in this field.

Total quality management is a relevant factor that could help firms meet their green performance objectives [15]. TQM is a control structure which can increase both individual and firm performance. This system enables companies to gain a competitive advantage and helps them maintain their advantage through improvements in standards and quality, at the lowest possible delivery time and at favourable cost [16,17]. Total quality management is an environment-oriented method which can help diminish waste through the effective and efficient consumption of resources and reserves [8]. Likewise, it involves the delivery of continuous progress, training, and development, and it enriches individual competencies to transform or better the performance of existing services or products [17-19].TQM therefore plays a vital role in boosting the ability of companies to attain green performance goals.

Furthermore, the idea of organizational culture has become popular in studies on social responsibility over the last decade. It offers an access point for corporate social performance in the fields of human resources and organizational behaviour. This system of words, shapes, categories, and images helps researchers interpret an individual's situation [19]. Studies have shown that an organization's culture requires mutual values that must be followed as officially authorized conduct $[20,21]$. Conventionally, qualitative approaches for analyzing organizational culture have been used [22]; however, it is impossible to create systematic comparisons through these research methods [23]. Hence, quantitative methods offer more practical understandings for cross-sectional organizational analysis and behavioural change projects, such as survey methods [24]. In previous research, organizational culture has also been analyzed with mixed qualitative and quantitative methods, e.g., Siehl and Martin [24].

Furthermore, trust in corporate culture can fundamentally change the way companies work, in addition to generating economic value for shareholders [25,26]. A company's working environment is composed of workers (including top management) and technological tools and skills under their usage. They have numerous conflicts that can dilute the more significant insights on how these constituencies think and view each other [27]. In the successful and smooth execution of a transition program, understanding the organizational culture plays a critical role [28,29]. TQM and CGP are a part of organizational culture and values in an organizational environment [30]. The creation of social responsibility is a shift in the orientation of values, with an emphasis on influencing attitudes and shaping personal roles to meet individual and public interests. Organizational culture is usually considered the primary reason why organizational change programs fail, for example, corporate social responsibility (CSR) and the adoption of environmental practices. Some scholars suggest that if the organization's fundamental culture remains the same, a change in methods, tactics, or strategies may result in failure [31]. Employee norms, beliefs, and values are likely to play a significant role in perceptions about TQM and the actions of employees [32]. Consequently, in companies with a sophisticated socially responsible culture, leaders and members are concerned for their own interests and benefits and acknowledge other stakeholders' needs [33]. Several studies suggest that organizational culture affects TQM and CGP's operating processes and effectiveness [30,34,35].

Expanding the concept of social responsibility from the developed world to the developing world is a challenge and an opportunity that ought to be taken on explicitly. Social responsibility and social responsiveness in healthcare would include both a new 
social aspect of care and new organizational practices within the health sector and other healthcare organizations [36]. However, malfeasance may ruin an organization, particularly a hospital or other healthcare organization [37]. This sector involves a varied group of stakeholders, such as patients, regulators, political authorities, health specialists, the media, the general public, and NGOs. All of these stakeholders expect that companies should understand their social and environmental obligations so that they might alleviate the adverse effects of their operations and contribute to the betterment of the community. Further, this sector has not yet fully received the attention of researchers in developing countries. This is especially true for Pakistan, where the health sector has never been examined in terms of either the implementation of TQM practices or green performance. Moreover, trust in corporate culture can fundamentally change the way companies work, in addition to generating economic value for shareholders $[25,26]$. In the successful and smooth implementation of any transition program, understanding the organizational culture plays a critical role [28,29]. Further, in organizational environment, TQM and CGP are considered a part of organizational culture [30]. Moreover, organizational culture has rarely been examined as a mediator between TQM practices and CGP in the health sector and the relevant target population.

Companies that implement green performance and quality management initiatives have the potential to address issues related to evolving consumer expectations about the environment and quality concerns [38,39]. Moreover, Fernando et al. [6] and Wang [40] believe that the concept of green performance is at the introductory stage, and that the literature in this area strongly needs to be enriched. Additionally, the research related to this issue has produced mixed results. For example, Li et al. [4] examined TQM's effect on Chinese manufacturing companies' green innovation performance and noticed a negative link between these factors. Similarly, Abbas and Sağsan [1] reported the same negative impact while measuring the effect of environmental management and quality management on firms' performance. Meanwhile, Tasleem et al. [41] found a positive and significant relationship between corporate sustainable development and total quality management practices. Moreover, Shahzad et al. [42] showed positive and significant outcomes in CSR due to the impact of knowledge absorptive capacity on CGP. Nevertheless, Zhang et al. [43] declared that CGP objectives were achieved only through technical and financial support from the government, because attempting to meet these objectives increased expenses and the time of production.

These mixed findings relating to TQM, CGP, and OC indicate the need for further study into the relationship between these variables. Besides, less attention has been paid to developing countries and their health sectors. This is the case for Pakistan, where the concepts of green performance and environmental sustainability are in the introductory phase, and where the relationship between TQM and CGP in the health sector has rarely been examined [4]. Thus, it is worth conducting a research study focusing on the health sector as a separate part of the service sector. Further, to gain a better understanding of TQM implementation in the hospital sector, the present study focuses on small and medium-sized private hospitals operating all over Pakistan. In particular, the purpose of this study is to enrich the existing literature by identifying and confirming the enablers and outcomes of TQM specifically within the hospital sector in the context of Pakistan. Moreover, the relationship between the implementation of TQM practices and green performance is also examined, given that past results relating to this issue have been contradictory. The current study also validates the argument that enhancements in the CGP of private hospitals can be achieved in an efficient manner through the implementation of TQM in developing countries. In addition, this research supports the argument that OC mediation affects the relationship between TQM and CGP in the health sector. To the best of the authors' knowledge, this mediation effect has not been previously investigated in previous TQM and green performance studies performed in Pakistan, thus adding another key contribution to the body of knowledge in TQM practices and green performance. 
Considering the significance of TQM in the modern world of business, this study shows how companies are able accomplish corporate green performance goals, how the private health sector is able utilize their essential tools (such as TQM), and how OC mediates this relationship. Following institutional theory and the American 'Malcolm Baldrige National Quality Award' (MBNQA), the researchers used five TQM practices, including strategic planning, customer focus, process management, human resource management, and information and analysis. Moreover, corporate green performance is quantified for two components, namely green management performance and green infrastructure, following the instructions of Li et al. [4] and Xie et al. [12]. Finally, OC is determined as per Adil's [44] recommendations. Thus, the following questions are addressed in the present article:

Research Question 1: What is the impact of TQM practices on corporate green performance? Research Question 2: Does organizational culture mediate the relationship between total quality management practices and corporate green performance?

\section{Structure of the Study}

Going forward, this paper is structured as follows: In Section 2, we briefly elaborate on the theoretical background, namely green theory and institutional theory, and introduce total quality management as a formative construct. In same section, we develop our hypotheses and introduce a comprehensive model. In Section 3, we discuss the methodology, namely, our sample, the measurement model, and the process of data collection. We present the results in Section 4, which are followed by a discussion on the implications and limitations (Section 5), as well as important conclusions (Section 6).

\section{Theoretical Background}

\subsection{Green Theory and Institutional Theory}

The level of natural resource utilization by the manufacturing sector has been massively high in terms of producing goods and making big money since the advent of the industrial revolution [45]. As per Ji and Zhang [3], this phenomenon has led to a dearth of natural resources, especially for forthcoming generations, and drastic changes to the environment in the form of global warming. In this respect, the United Nations Global Compact (UNGC) proclaimed it mandatory worldwide for all organizations to adopt environmentally sustainable strategies and green traditions [46]. UNGC is the most prominent initiator of environmental sustainability globally, comprising of more than 12,500 signatories from over 160 countries, both commercial and non-commercial. Considering Raimi's [47] recommendations, the environmentalists have urged organizations to incorporate CSR programs and green mindsets within their processes. This reflects the impact on organizational financial performance in a positive and significant way and on social impacts.

Green theory, a modern interdisciplinary style of thought, has been conceptualized by Eckersley [48] and centres on sustainability, globalization, corporate responsibility towards society, corporate governance, and social rights forms. At all three levels (local, state, and international) green theory seeks to ensure environmental sustainability. According to Cancino et al. [49], green performance derives its conceptual origins from CGP and green theory as it relates to an organization's activities and the environment. This offers vital details about companies' structures and their adherence to natural environmental standards, describing the efficacy and efficiency of organizational behaviour towards the environment [50]. The organization is focused on turning operations into environmentally friendly practices by introducing fundamental changes into product or service operating processes to become a green organization [51].

In this paper, institutional theory is used to explicate the process of introducing TQM practices within health sector. The literature on TQM practices tends to be outcome-oriented and there are only a few studies employing a processual approach. Institutional theory has been little used to study such processes as it has tended to be seen as a theory of stability rather than change [52,53]. Seo and Creed [54] question the emphasis on stability 
in conventional institutional theory, which they identify as the problem of "embedded agency". Embedded agents are those whose actions are constrained by the prevailing institutional ways of behaving. This means management may need the services of external consultants to bring about institutional change [55].

Services providers and manufacturing companies, in particular, aim to shift the conventional product lifecycle view from resource extraction to production, distribution, use, and recycling, as per environmental standards [56]. Companies aspiring to green strategies have enormous potential to gain market share [57]. Therefore, concerned authorities and management support are necessary to enable businesses to move from conventional production to green operating sources [43]. Green performance can be determined by green management practices following Li et al. [4], Xie et al. [12], and Abbas [58], who split green technology into two sub-practices, termed green management and green infrastructure, which are defined as follows:

- Green management practices denote the restructuring or development of new policies related to the management structures that mitigate the detrimental effect of firm production strategies and transform them towards environmentally sustainable systems [4].

- Green infrastructure is the process of forming and utilizing resource-efficient and environmentally friendly processes over the building's life cycle, from place to create, construction, repair, service, reconstruction, and deconstruction [59].

\subsection{Total Quality Management}

TQM is a management system that concentrates on quality improvement through the application of instruments, values, and processes [60]. TQM aims to raise consumer satisfaction by increasing the quality of goods and services, while at the same time consuming the lowest number of resources [15]. The root of TQM's definition comes from definitions of quality. In general, quality was defined as a predictable degree of uniformity and dependability at a low cost and suited to the market [61]. On the other hand, Cosby and Juran's definition focused on designing products and services that meet customers' needs and expectations [62]. Kiran [63] defined quality as "fitness for use", "fitness for purpose", "customer satisfaction", "conformance to the requirements", or as a pragmatic interpretation relating to the non-inferiority (or superiority) of something. In ISO 9000, quality was described as "the degree to which a set of inherent characteristics fulfills requirements". Therefore, according to Peter Drucker: "quality is not what the supplier puts in, it is what the customer gets out and is willing to pay for". Based on the concept of quality, the idea of total quality management has been developed as a result of intense global competition [64]. Defining TQM is a matter of controversy among researchers because of distinctions between TQM's content, elements, and processes. When focused on content, TQM has been considered as a management philosophy, the major business strategy in the 1990s, or as one form of operations management practices [65-67]. According to Abdullah [68], TQM is "a philosophy and a set of guiding principles" to combine not only management techniques, but also technical tools, as well as improvement efforts in a stable technical system with continuous improvement targets for managing a firm. Furthermore, TQM is used as a way of continuous improvement, and it has been recognized as a commitment to customers [69,70]. In the research of Kanji [71], TQM is understood as a commitment to customer satisfaction through continuous improvement. In this way, the implementation of TQM can reduce costs, increase profits, and secure market share. As Berry [72] explained: the TQM process is a total corporate system with the goal of meeting and exceeding customers' expectations and reducing costs. The implementation of TQM involves the whole organization so that researchers can understand the activities of each individual at each level [73]. Madu [62] also defined TQM "as an organization-wide quality program to continuously improve products and services delivered to customers by developing supportive organizational culture and implementing statistical and management tools". This definition shows that TQM is a holistic concept for improving the quality of 
products and services by involving all processes and activities in companies for ensuring quality management. For this concept, quality management is the responsibility of not only the quality department or board of directors, but of all employees in the organization. Achieving the totality of TQM requires joint collaborative efforts of all departments and all members of the company, as Wilkinson and Witcher [74] have stated. TQM therefore contains three simple equations: total, meaning the participation of everyone; quality, meaning meeting customer requirements accurately; and management, meaning enabling conditions for total quality. Moreover, as QM has been recognized as a competitive advantage, a surge in its implementation in various operational and financial performance measures has been reported [75]. Hard QM is generally defined as QM practices that focus on controlling processes and products through techniques and tools in order to conform to and satisfy established requirements [76,77]. Similar to Zeng et al. [78], we consider the following two most important hard QM elements: process management and quality information. Soft QM can be generally defined as the QM practices that are directed toward involvement and commitment of management and employees, training, learning, and internal cooperation or teamwork-in other words, promoting the human aspects of the system $[76,79]$. In this this study, the hard side is covered by process management and information and analysis, while the soft side is based on strategic planning, customer focus, and human resource management.

\subsection{Research Framework and Hypothesis Development}

Tables 1 and 2 summarize study results of positive and negative (or non-significant) relationships or correlations between TQM practices and various performance measures, respectively. Figure 1 shows the proposed research model of the relationship between TQM practices and corporate green performance. The literature contains both negative and positive arguments about the relationship between TQM practices and firm performance. Prajogo and Sohal [80], have contended that employees of TQM firms work to improve the existing system incrementally by focusing on the details of the current quality process, rather than new ideas that might substantially change the current system of work. In addition, "management by fact" necessitates a set of data, tools, and techniques with which to analyze the existing system, leading to solutions based on prior experience and inhibiting quality-related solutions. The negative viewpoint states that TQM practices focus on improving the process by eliminating waste and obtaining efficiency and are not compatible with a firm's green performance. Thus, the following hypothesis is proposed.

Table 1. Literature review of positive or significant relationship between TQM practices and performance.

\begin{tabular}{cccc}
\hline TQM Practices & $\begin{array}{c}\text { Market and Financial } \\
\text { Performance }\end{array}$ & Operating Performance & Employee Performance \\
Strategic Planning & $\begin{array}{c}\text { Nair [81], Sanchez-Rodriguez } \\
\text { and Martinez-Lorente [82], } \\
\text { Adam et al. [83], Kannan and } \\
\text { Tan [84], Fuentes et al. [85]. }\end{array}$ & $\begin{array}{c}\text { Ahire and Dreyfus [86], } \\
\text { Fuentes et al. [85]. }\end{array}$ & Cua et al. [87]. \\
\hline Customer Focus & Fuentes et al. [85], Nair [81]. & $\begin{array}{c}\text { Fuentes et al. [85], Nair [81], } \\
\text { Cua et al. [87], Flynn et al. } \\
\text { [88]. }\end{array}$ & Nair [81]. \\
\hline Process Management & $\begin{array}{c}\text { Wilson and Collier [89], Nair } \\
\text { [81], Ahire and Dreyfus [86]. }\end{array}$ & $\begin{array}{c}\text { Flynn et al. [88], Fuentes et al. } \\
\text { [85]. }\end{array}$ & $\begin{array}{c}\text { Nair [81], Cua et al. [87] } \\
\text { [85], Pham [90]. }\end{array}$ \\
\hline Kuman Resource & $\begin{array}{c}\text { Kaynak [75], Fuentes et al. } \\
\text { [91], Fuentes et al. [85]. }\end{array}$ & $\begin{array}{c}\text { Anderson et al. [91], Fuentes } \\
\text { et al. [85]. }\end{array}$ \\
\hline
\end{tabular}


Table 1. Cont.

\begin{tabular}{|c|c|c|c|}
\hline TQM Practices & $\begin{array}{l}\text { Market and Financial } \\
\text { Performance }\end{array}$ & Operating Performance & Employee Performance \\
\hline Information and Analysis & $\begin{array}{l}\text { Choi and Eboch [92], Prajogo } \\
\text { and Sohal [80], Al-Bishari and } \\
\text { Khalil. [93]. }\end{array}$ & Wilson and Collier [89]. & Nair [81]. \\
\hline Overall TQM Practices & $\begin{array}{l}\text { Hendricks and Singhal [94], } \\
\text { Easton and Jarrell [95], } \\
\text { Douglas and Judge [96], } \\
\text { Mohrman et al. [97], } \\
\text { Sanchez-Rodriguez and } \\
\text { Martinez-Lorente [98], } \\
\text { Abbas [13]. }\end{array}$ & $\begin{array}{l}\text { Cua et al. [87], Dow et al. [99], } \\
\text { Shah and Ward [100], } \\
\text { Anderson et al. [91], Tata et al. } \\
\text { [101], Carter and Narasimhan } \\
\text { [102], Abbas [13]. }\end{array}$ & Sun [103], Ismail et al. [104]. \\
\hline
\end{tabular}

Table 2. Literature review of negative or non-significant relationship between TQM practices and performance.

\begin{tabular}{cccc}
\hline TQM Practices & $\begin{array}{c}\text { Market and Financial } \\
\text { Performance }\end{array}$ & Operating Performance & Employee Performance \\
\hline $\begin{array}{c}\text { Strategic Planning } \\
\text { Customer Focus } \\
\text { Process Management } \\
\text { Human Resource }\end{array}$ & $\begin{array}{c}\text { Kannan and Tan [84]. } \\
\text { Rahman and Bullock [105]. } \\
\text { Management }\end{array}$ & Choi and Eboch [92]. & - \\
Information and Analysis & - & - & - \\
Overall TQM Practices & - & - & Rungtusanatham et al. [91]. \\
& $\begin{array}{c}\text { York and Miree [107], Iqbal } \\
\text { et al. [108], Li et al. [4]. }\end{array}$ & Yang et al. [106]. & Sadikoglu [109]. \\
\hline
\end{tabular}

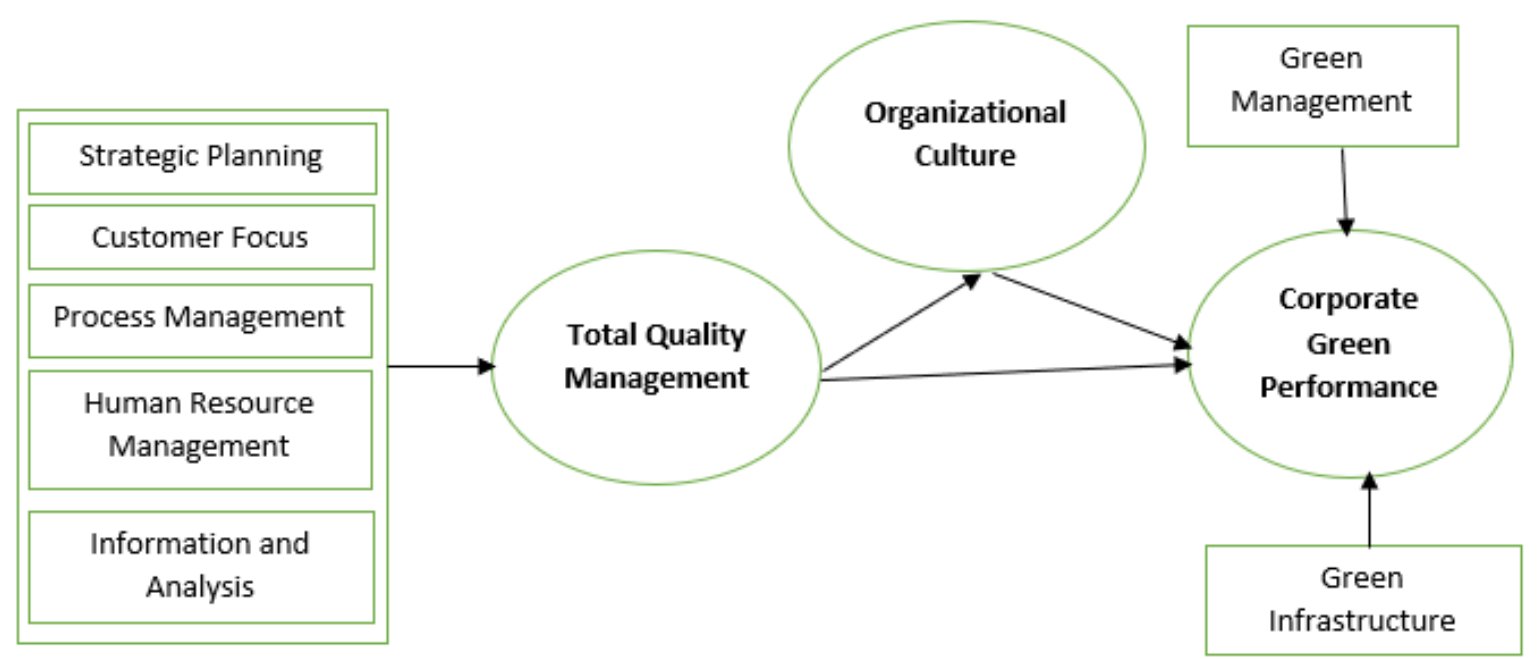

Figure 1. Total quality management, corporate green performance and organizational culture.

The US-based MBNQA is a widely renowned quality award for corporations [110], known for its contribution to modernizing countless individuals and private organizations in terms of management values and competitive advantage [111]. The present paper applied five dimensions of the MBNQA: strategic planning, customer focus, process management, human resource management, and information and analysis, following Yusr et al. [16] and Ooi [112]. 


\subsubsection{Strategic Planning}

The relevant consideration for TQM and socially responsible activities is strategic planning (SP). London [113] indicated that the application of TQM involves a consistent strategic company plan; for example, by putting in place a constructive strategic plan which is continuously evaluated and which enhances a firm's sustainability and efficiency [114]. Such strategic goals are built based on the vision, goals, and purpose of an organization; therefore, the organizational strategy should concentrate on balancing its stakeholders' desires and needs. A company's vision statement should signify its vision and plan, and such plans can comprise a strategic plan, quality policy, and strategy, or a plan for quality management and quality practice benchmarks $[115,116]$. Consequently, for this research paper, the following hypotheses are proposed:

Hypothesis 1. SP has a positive influence on CGP.

Hypothesis 1a. SP has a positive influence on OC.

Hypothesis $\mathbf{1 b}$. OC significantly mediates the relationship between SP and CGP.

\subsubsection{Customer Focus}

As an organizational approach, customer focus (CF) illustrates all facets of a firm's production and distribution of products or services that are focused on customer preferences [103]. The key aim of TQM activities is to fulfil customer requirements and meet their standards $[91,117,118]$. Customer emphasis stresses an improvement in customer satisfaction in the sense of TQM and green practices, but companies are also expected to follow ethical principles. For instance, organizations do not offer any goods that have harmful effects on consumers' health [119]. Moreover, as part of CSR procedures, companies are expected to warn their clients about materials in their products that will impact a consumer's use (such as goods containing alcohol and nicotine) [104]. For the current research, the following hypotheses are proposed under CF:

Hypothesis 2. CF has a positive influence on CGP.

Hypothesis 2a. CF has a positive influence on OC.

Hypothesis $\mathbf{2 b}$. OC significantly mediates the relationship between CF and CGP.

\subsubsection{Process Management}

According to Porter and Parker [120], process management (PM) is a core component of the quality strategy. It refers to a set of operations designed by a company to manufacture value-added goods and services to its clients and other stakeholders [121,122]. Companies must continuously find methods to improve processes, to be efficient, and to participate in lean innovation [80]. Sadikoglu and Zehir [109] emphasize that process management can boost a product's consistency by reducing processing variations, leading to increased operational efficiency, creativity, and productivity gains [80]. In addition, successful process management design would minimize the adverse effects on the natural environment, resulting in cost savings and benefit growth [89]. The following suggested hypotheses for this research article under PM are:

Hypothesis 3. PM has a positive influence on CGP.

Hypothesis 3a. PM has a positive influence on OC.

Hypothesis $\mathbf{3 b}$. OC significantly mediates the relationship between PM and CGP. 


\subsubsection{Human Resource Management}

Another significant aspect that leads to an enterprise's long-term sustainability is human resource management (HRM) for the execution of quality and social programs [123,124]. The skills and capabilities of a firm's workers are essential to achieving competitive advantage [125]. Employers are equally important as they deliver inspiration, innovation, vision, and encouragement, leading an organization towards success [121]. As a result, productive HRM can develop recognition protocols and offer a reward or prize for quality practices [126]. HRM practices can increase workers' dedication to the application of TQM practices and foster an environment of socially responsible culture [24,127-130]. The following proposed hypotheses for this research are:

Hypothesis 4. HRM has a positive influence on CGP.

Hypothesis 4a. HRM has a positive influence on OC.

Hypothesis $\mathbf{4 b}$. OC significantly mediates between HRM and CGP.

\subsubsection{Information and Analysis}

Information and analysis (IA) is interconnected to the organizational learning element of TQM, such as evaluating the performance of managers and employees, keeping the information of organizational procedures, recommending solutions to employee issues, and managing and using operational and business information to make appropriate decisions [58]. Effective and sustainable handling of knowledge can help a company meet the quality requirements of high-quality goods for the manufacture of materials. Therefore, companies would reduce process variability and the incidence of damaged products and control their stock and supplies [131]. Organizations emphasize and have stated concern about the ability of environmentally sustainable goods and services to meet corporate social responsibility requirements due to the complexities of knowledge and the examination of increased environmental pressures from many stakeholders [132]. The following suggested hypotheses for this research are:

Hypothesis 5. IA has a positive influence on CGP.

Hypothesis 5a. IA has a positive influence on OC.

Hypothesis $5 \mathbf{b}$. OC significantly mediates between IA and CGP.

\subsection{Organizational Culture}

Pettigrew [19] described culture as "the system for a given group at a given time of such publicly and collectively accepted meanings operating for a certain group" (p. 574). This system of words, shapes, categories, and images is interpreted by each individual as their situation [19]. In reality, an organization's culture requires mutual values that must be followed as a matter of officially authorized conduct $[20,21]$. Conventionally, qualitative approaches for analyzing organizational culture have been used [22]; however, it is impossible to create systematic comparisons through these research methods [23]. Hence, quantitative methods offer more practical understandings for cross-sectional organizational analysis and behavioural change projects, such as survey methods [133]. In previous research, organizational culture has also been analyzed with mixed qualitative and quantitative methods, e.g., Siehl and Martin [23]. 
Furthermore, trust in corporate culture can fundamentally change the way companies work, in addition to generating economic value for shareholders [24-26]. A company's working environment is composed of workers (including top management) and technological tools and skills under their usage. They have numerous conflicts that can dilute the more significant insights on how these constituencies think and view each other [27]. In the successful and smooth execution of a transition program, understanding the organizational culture plays a critical role [28,29]. The direct correlation between employee attitudes and organizational culture required to institutionalize effective organizational change has also been verified by past literature [134]. For the current analysis, the following hypothesis is proposed. Further, Figure 2 demonstrates the all hypothetical relationships of the present study.

Hypothesis 6. OC has a positive influence on CGP.

\section{TQM Practices}

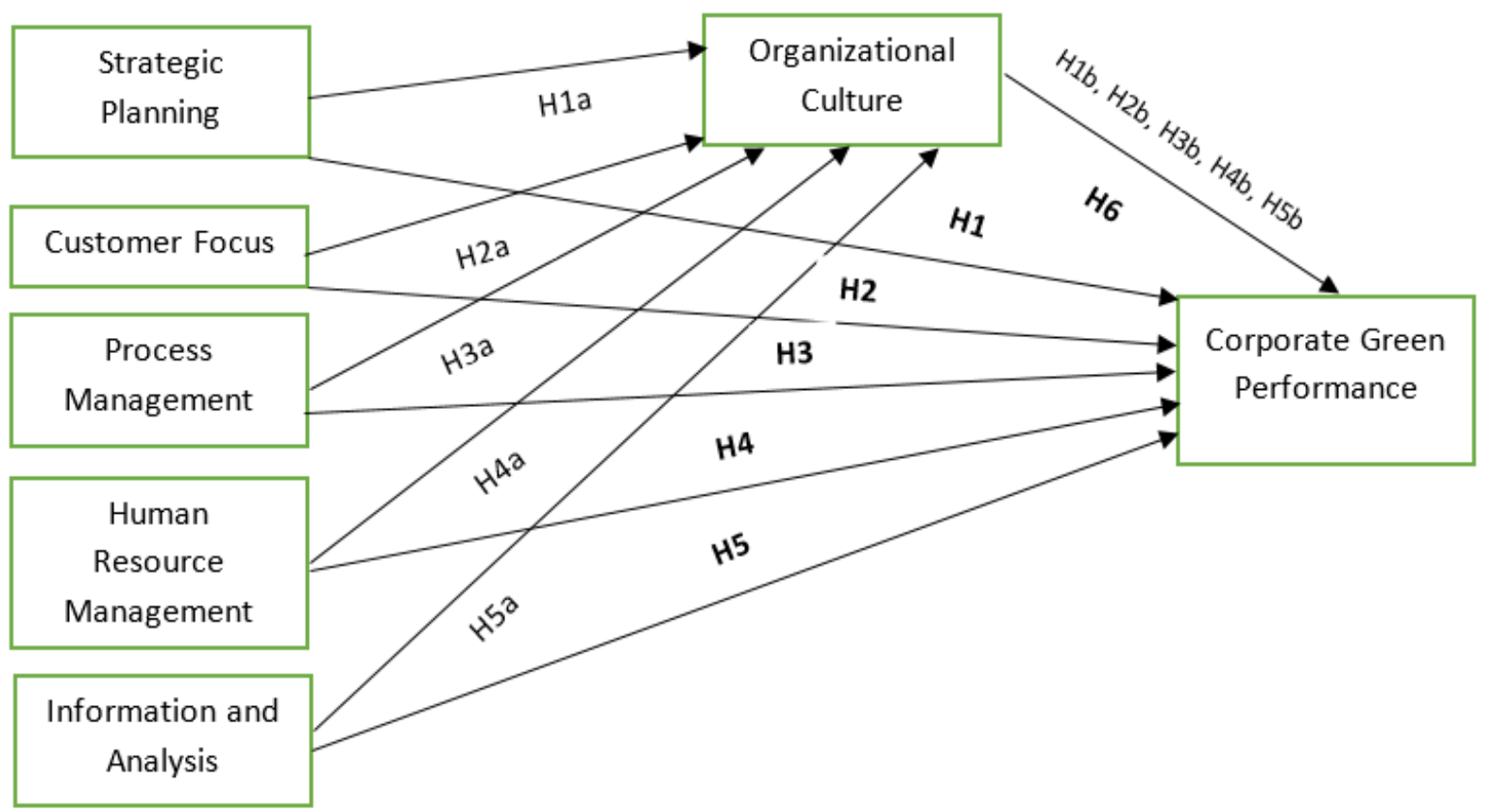

Figure 2. Conceptual Framework.

\section{Research Methodology}

\subsection{Sampling Procedure and Target Population}

The abovementioned mixed findings relating to TQM, CGP, and OC offer a compelling reason for a comprehensive study of the relationship between these variables. Furthermore, less attention has been paid to developing countries, such as Pakistan, where the concepts of green performance and environmental sustainability are in the introductory phase, and where the relationship between TQM and CGP in the health sector has rarely been examined [4]. Thus, it is worth conducting a research study focusing on the health sector as a separate part of the services sector. The target population for the current research was large and medium-sized private hospitals listed with the Ministry of National Health Services Control and Coordination of Pakistan (NHSRC). The NHSRC is the most detailed and most extensive catalogue of hospitals functioning in Pakistan. Han et al. [135] concluded that ISO 9000 certification efforts and TQM practices have a significant and positive relationship, and that ISO 9000 certification may be the first step for TQM implementation. Furthermore, 


\begin{abstract}
Abdullah [68] suggested that ISO 9000 provided a structured approach for the development and implementation of quality management systems. Still, it is only considered as a minimal standard for an excellent quality management system. Therefore, companies should consider implementing ISO 9000 standards as the first milestone in the path to TQM and quality excellence. Similarly, the researchers approached only ISO 9001 accredited hospitals who have, have applied for, or plan to use ISO 14001 and 26000 certificates. These contradictory findings on TQM, CGP, and OC highlight the compelling need for a complete investigation of the link between these factors. Furthermore, in developing countries and on concerned sectors, such as Pakistan, less attention has been paid to the concerned relationship of TQM and CGP, where the concepts of green performance and environmental sustainability are still in their infancy and the health sector has rarely been touched for such relationships [4].The data was collected from large and medium-sized private hospitals situated in six major commercial cities in Pakistan, namely Karachi, Lahore, Multan, Islamabad, Peshawar, and Faisalabad, via personal visits during August 2020 to October 2020 and following a non-probability convenience sampling technique. The selection of the abovementioned cities was based on population density, literacy rate, and on their having highly developed hospitals with modern facilities. Besides, the three major provinces of Pakistan were also represented by these cities; for example, Karachi represents the province of Sindh; Lahore, Multan, and Faisalabad represent Punjab; Peshawar represents the province of Khyber Pakhtunkhwa (KP); and Islamabad is a separate territory and the capital of Pakistan. The researchers congregated data from management personnel at the lower, middle, and upper levels, providing detailed information on organizational policies and practices. In addition, they are also the key people in their organizations who exchange data and enforce organizational policies. The present research's total population includes a total of 180 private hospitals from 124 medium- and 56 large-size private hospitals listed with the NHSRC. The target population of 180 was sampled at a $95 \%$ confidence level with a $\pm 5 \%$ confidence interval, meaning the sample size was 123 private hospitals. Firstly, the personnel responsible for TQM, CSR, CGP, and OP in the targeted private hospitals were approached using purposive sampling. Afterwards, they advised the next respondents in the hospitals for all lower, middle, and upper-level management staff, meaning that snowball sampling was used. Following this approach, the total number of respondents in this research was 369 respondents $(=123 \times 3)$. The researcher obtained 369 responses which were used for data analysis in response to 123 targeted private hospitals. In Tables 3 and 4 , detailed demographic information is provided.
\end{abstract}

Table 3. City-wide list of contacted and responded hospitals with accurate responses.

\begin{tabular}{|c|c|c|c|c|c|c|}
\hline Province & Cities & $\begin{array}{l}\text { Number of } \\
\text { Private } \\
\text { Hospitals } \\
\text { (Medium) }\end{array}$ & $\begin{array}{l}\text { Number of } \\
\text { Private } \\
\text { Hospitals } \\
\text { (Large) }\end{array}$ & $\begin{array}{l}\text { Questionnaire } \\
\text { Distributed }\end{array}$ & $\begin{array}{l}\text { Response from } \\
\text { Hospitals } \\
\text { (Medium) }\end{array}$ & $\begin{array}{c}\text { Response from } \\
\text { Hospitals } \\
\text { (Large) }\end{array}$ \\
\hline Sindh & Karachi & 17 & 7 & 72 & 51 & 21 \\
\hline Punjab & Lahore & 15 & 8 & 69 & 45 & 24 \\
\hline- & Multan & 10 & 6 & 48 & 30 & 18 \\
\hline - & Faisalabad & 15 & 7 & 66 & 45 & 21 \\
\hline $\begin{array}{c}\text { Capital City } \\
\text { (Separate } \\
\text { Territory) } \\
\text { Khyber }\end{array}$ & Islamabad & 19 & 8 & 81 & 57 & 24 \\
\hline \multirow[t]{2}{*}{$\begin{array}{l}\text { Pakhtunkhwa } \\
\text { (KP) }\end{array}$} & Peshawar & 8 & 3 & 33 & 24 & 9 \\
\hline & Total & 84 & 39 & 369 & 252 & 117 \\
\hline
\end{tabular}


Table 4. Demographic Information $(n=369)$.

\begin{tabular}{cccc}
\hline Specifics & Description & Values & Percentage \\
\hline \multirow{3}{*}{ Gender } & Male & 220 & $59.60 \%$ \\
& Female & 149 & $40.40 \%$ \\
& SUM & 369 & $100.00 \%$ \\
\hline \multirow{3}{*}{ Total Responses } & Medium & 252 & $68.29 \%$ \\
& Large & 117 & $31.71 \%$ \\
& SUM & 369 & $100.00 \%$ \\
\hline \multirow{3}{*}{ Job Level } & Lower Management & 123 & $33.33 \%$ \\
& Middle Management & 123 & $33.33 \%$ \\
& Upper Management & 123 & $33.33 \%$ \\
& SUM & 369 & $100.00 \%$ \\
\hline \multirow{3}{*}{ Years of Experience } & Less than 6 Years & 175 & $47.42 \%$ \\
& 6-10 Years & 93 & $25.10 \%$ \\
& More than 15 Years & 87 & $23.71 \%$ \\
& SUM & 14 & $3.77 \%$ \\
& & 369 & $100.00 \%$ \\
\hline
\end{tabular}

\subsection{Instrument Design}

The instrument of the current article comprised of 39 questions that determine the seven main variables stated in Appendix A. The questions used in this study to measure each construct through formative measure theory were adopted from several authors who have written on the subject of corporate green performance $[4,13]$, organizational culture $[44,136]$, strategic planning (SP), customer focus (CF), process management (PM), human resource management (HRM), and information and analysis (IA) [111]. The questionnaires included a letter of introduction from the researcher's academic institution, and within the letter of introduction, the objectives and the merits of the research were outlined. The respondents' anonymity and confidentiality were ensured entirely.

Certain questions were reversed from negative to positive and vice versa to avoid biased results before conducting the actual survey. Moreover, the researcher has performed some causality tests to ensure the relationship's direction; however, for the purpose of brevity, the results are not reported in the document. Following Hair et al. [137], SmartPLS is used for structure equation modeling (SEM).

\subsection{Demographic Variable Description}

Following Ooi [49], hospital size was considered to be a demographic variable in this research, as large hospitals or companies have more capital and infrastructure than small companies. The researchers divided hospitals into two groups (medium and large) as per their number of staff or employees by considering the recommendations of Hoang et al. [94]. Following this approach, hospitals with less than one hundred personnel were judged to be medium-sized, while hospitals were considered to be large if they had more than a hundred employees. Table 4 explains the demographic profile of respondents.

\section{Data Analysis and Results}

PLS-SEM is used to analyze data in this study due to its ability to measure complicated models. It is generally more appropriate to use when the study includes numerous variables and complex models together [137]. Khalil et al. [138], Khalil et al. [139] and Hair et al. [137] propose that PLS-SEM can offer a strong ground for the confirmation of theories and obtain results that help us explain the application of theories.

Structure equation modelling is composed of two sub-models in SmartPLS: (1) the inner model and (2) the outer model. The internal model applies to the relationship between the dependent and independent variables, while the external or outer model defines the relationship between the dependent variables and specified indicators [137]. Further, for testing common method bias, this study used Lindell and Whitney's [140] and 
Podsakof et al.'s [141] method. In this study, we employ a theoretically unrelated construct (innovation) to adjust the correlation among the principal constructs. For instance, the "InnVar" is used as the innovation variable. After running the test, the correlation between Innovation and other variables, such as innovation and strategic planning or innovation and culture, is very low. After squaring the correlation, the maximum shared variance with the other variables can be noticed. The maximum shared variance was about 0.1 , so we can conclude that we do not have common method bias.

The presentation of results in this study follows the style explained by Henseler et al. [142]. At first, regarding their style, the reliability and validity of the concerned variables needed to be checked by generating reliable estimates using the PLS algorithm for the outer model, which also refers to a measurement model. Later, a structural model was estimated by using the bootstrapping option for the inner model in SmartPLS. The results in Figure 3 demonstrate the estimation of the measurement model in which we generally estimate the relationships between the construct (latent variable) and its indicators.

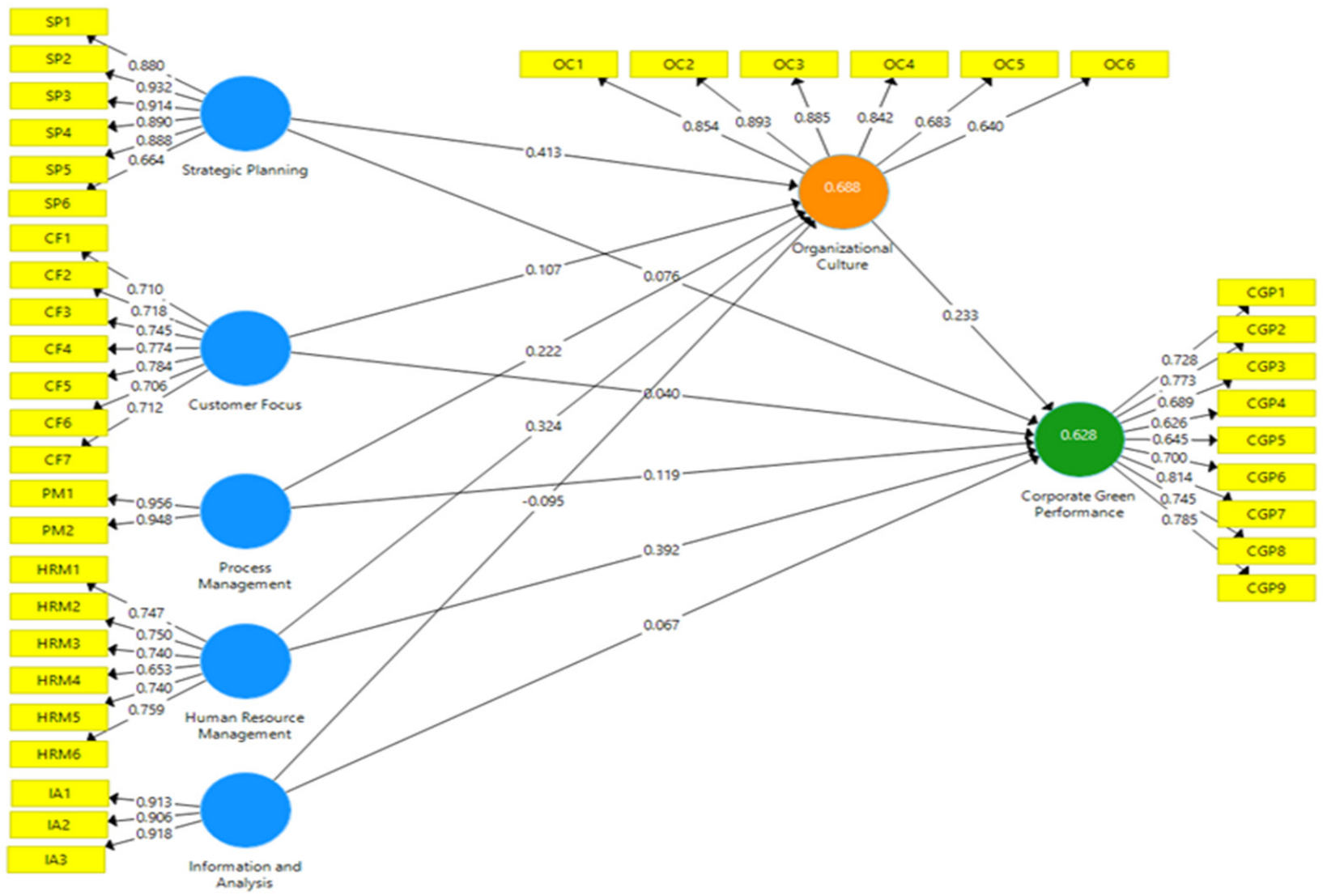

Figure 3. Measurement Model Results.

The results of Cronbach's alpha, composite reliability, and average variance extracted (AVE) for the variables used in this study are shown in Table 5. Results clearly show that all the Cronbach's alpha and composite reliability (CR) values are higher than 0.7 , surpassing the minimum acceptable criteria. For each variable, AVE's values are more than 0.5 , which meets the criteria for acceptable convergent validity.

Discriminant validity shows that each variable's measure is significantly related to its variable and less allied to other variables in the study [98]. There are two tests for discriminant validity: (1) cross-loading; and (2) the Fornell-Larcker test. Cross-loading is used to measure the indicator level of discriminant validity, while the Fornell-Larcker test is a test to measure the variable level of discriminant validity. 
Table 5. Results of Cronbach's Alpha, CR and AVE.

\begin{tabular}{cccc}
\hline Variables & $\begin{array}{c}\text { Cronbach's Alpha } \\
\text { Values }\end{array}$ & CR Values & AVE Values \\
\hline Strategic Planning & 0.931 & 0.947 & 0.750 \\
Customer Focus & 0.860 & 0.892 & 0.542 \\
Process Management & 0.898 & 0.951 & 0.907 \\
Human Resource Management & 0.829 & 0.874 & 0.537 \\
Information and Analysis & 0.900 & 0.937 & 0.833 \\
Organizational Culture & 0.887 & 0.916 & 0.649 \\
Corporate Green Performance & 0.887 & 0.908 & 0.526 \\
\hline
\end{tabular}

The values for cross-loadings are shown in Table 6. Results demonstrate that all indicators have the highest relationship with their variables.

Table 6. Cross Loadings.

\begin{tabular}{|c|c|c|c|c|c|c|c|}
\hline Indicators & $\begin{array}{l}\text { Strategic } \\
\text { Planning }\end{array}$ & $\begin{array}{l}\text { Customer } \\
\text { Focus }\end{array}$ & $\begin{array}{c}\text { Process } \\
\text { Management }\end{array}$ & $\begin{array}{c}\text { Human } \\
\text { Resource } \\
\text { Management }\end{array}$ & $\begin{array}{l}\text { Information } \\
\text { \& Analysis }\end{array}$ & $\begin{array}{l}\text { Organizational } \\
\text { Culture }\end{array}$ & $\begin{array}{l}\text { Corporate } \\
\text { Green } \\
\text { Performance }\end{array}$ \\
\hline SP1 & 0.880 & 0.447 & 0.470 & 0.483 & 0.402 & 0.662 & 0.482 \\
\hline SP2 & 0.932 & 0.469 & 0.472 & 0.495 & 0.446 & 0.662 & 0.515 \\
\hline SP3 & 0.914 & 0.429 & 0.470 & 0.491 & 0.427 & 0.634 & 0.504 \\
\hline SP4 & 0.890 & 0.493 & 0.513 & 0.511 & 0.419 & 0.655 & 0.561 \\
\hline SP5 & 0.888 & 0.422 & 0.526 & 0.503 & 0.408 & 0.655 & 0.554 \\
\hline SP6 & 0.664 & 0.320 & 0.391 & 0.411 & 0.414 & 0.461 & 0.386 \\
\hline CF1 & 0.285 & 0.710 & 0.255 & 0.572 & 0.435 & 0.356 & 0.368 \\
\hline CF2 & 0.351 & 0.718 & 0.299 & 0.551 & 0.473 & 0.347 & 0.355 \\
\hline CF3 & 0.413 & 0.745 & 0.312 & 0.539 & 0.369 & 0.447 & 0.373 \\
\hline CF4 & 0.444 & 0.774 & 0.420 & 0.628 & 0.484 & 0.545 & 0.526 \\
\hline CF5 & 0.410 & 0.784 & 0.400 & 0.677 & 0.539 & 0.475 & 0.527 \\
\hline CF6 & 0.303 & 0.706 & 0.375 & 0.531 & 0.259 & 0.467 & 0.479 \\
\hline CF7 & 0.349 & 0.712 & 0.388 & 0.568 & 0.308 & 0.517 & 0.540 \\
\hline PM1 & 0.544 & 0.464 & 0.956 & 0.550 & 0.438 & 0.626 & 0.578 \\
\hline PM2 & 0.500 & 0.461 & 0.948 & 0.510 & 0.435 & 0.586 & 0.522 \\
\hline HRM1 & 0.341 & 0.581 & 0.347 & 0.747 & 0.527 & 0.479 & 0.476 \\
\hline HRM2 & 0.368 & 0.581 & 0.390 & 0.750 & 0.473 & 0.463 & 0.425 \\
\hline HRM3 & 0.362 & 0.668 & 0.394 & 0.740 & 0.458 & 0.482 & 0.522 \\
\hline HRM4 & 0.391 & 0.516 & 0.390 & 0.653 & 0.739 & 0.375 & 0.506 \\
\hline HRM5 & 0.450 & 0.530 & 0.451 & 0.740 & 0.397 & 0.590 & 0.579 \\
\hline HRM6 & 0.501 & 0.608 & 0.454 & 0.759 & 0.375 & 0.624 & 0.683 \\
\hline IA1 & 0.419 & 0.536 & 0.455 & 0.630 & 0.913 & 0.421 & 0.492 \\
\hline IA2 & 0.449 & 0.489 & 0.401 & 0.553 & 0.906 & 0.391 & 0.486 \\
\hline IA3 & 0.450 & 0.490 & 0.400 & 0.611 & 0.918 & 0.487 & 0.523 \\
\hline OC1 & 0.663 & 0.403 & 0.533 & 0.491 & 0.383 & 0.854 & 0.533 \\
\hline OC2 & 0.668 & 0.427 & 0.576 & 0.503 & 0.397 & 0.893 & 0.517 \\
\hline OC3 & 0.668 & 0.431 & 0.561 & 0.512 & 0.404 & 0.885 & 0.510 \\
\hline OC4 & 0.661 & 0.392 & 0.609 & 0.505 & 0.393 & 0.842 & 0.519 \\
\hline OC5 & 0.413 & 0.694 & 0.401 & 0.662 & 0.338 & 0.683 & 0.628 \\
\hline OC6 & 0.398 & 0.644 & 0.377 & 0.679 & 0.371 & 0.640 & 0.626 \\
\hline CGP1 & 0.461 & 0.427 & 0.470 & 0.519 & 0.348 & 0.512 & 0.728 \\
\hline CGP2 & 0.405 & 0.433 & 0.404 & 0.485 & 0.439 & 0.456 & 0.773 \\
\hline CGP3 & 0.432 & 0.357 & 0.355 & 0.420 & 0.370 & 0.484 & 0.689 \\
\hline CGP4 & 0.374 & 0.304 & 0.308 & 0.383 & 0.398 & 0.350 & 0.626 \\
\hline CGP5 & 0.438 & 0.389 & 0.463 & 0.475 & 0.433 & 0.500 & 0.645 \\
\hline CGP6 & 0.437 & 0.576 & 0.448 & 0.642 & 0.367 & 0.588 & 0.700 \\
\hline CGP7 & 0.448 & 0.581 & 0.451 & 0.666 & 0.440 & 0.567 & 0.814 \\
\hline CGP8 & 0.404 & 0.438 & 0.415 & 0.558 & 0.361 & 0.477 & 0.745 \\
\hline CGP9 & 0.397 & 0.520 & 0.429 & 0.596 & 0.437 & 0.550 & 0.785 \\
\hline
\end{tabular}


The results of the Fornell-Larcker test are illustrated in Table 7. For a construct to stand valid, it must have more variance with its indicators than with other variables' measures. Results show that all variables share the highest variance with their variables. Furthermore, the present study meets the required criteria of the heterotrait-monotrait (HTMT) ratio that was suggested by Hair et al. [95] (see Table 8).

Table 7. Fornell-Larcker Criterion.

\begin{tabular}{|c|c|c|c|c|c|c|c|}
\hline Variable & $\begin{array}{c}\text { Corporate } \\
\text { Green } \\
\text { Performance }\end{array}$ & $\begin{array}{l}\text { Customer } \\
\text { Focus }\end{array}$ & $\begin{array}{c}\text { Human } \\
\text { Resource } \\
\text { Management }\end{array}$ & $\begin{array}{l}\text { Information } \\
\text { and Analysis }\end{array}$ & $\begin{array}{l}\text { Organizational } \\
\text { Culture }\end{array}$ & $\begin{array}{c}\text { Process } \\
\text { Management }\end{array}$ & $\begin{array}{l}\text { Strategic } \\
\text { Planning }\end{array}$ \\
\hline $\begin{array}{c}\text { Corporate } \\
\text { Green } \\
\text { Performance }\end{array}$ & 0.725 & & & & & & \\
\hline $\begin{array}{l}\text { Customer } \\
\text { Focus }\end{array}$ & 0.630 & 0.736 & & & & & \\
\hline $\begin{array}{c}\text { Human } \\
\text { Resource } \\
\text { Management }\end{array}$ & 0.740 & 0.793 & 0.732 & & & & \\
\hline $\begin{array}{l}\text { Information } \\
\text { and Analysis }\end{array}$ & 0.549 & 0.553 & 0.656 & 0.912 & & & \\
\hline $\begin{array}{l}\text { Organizational } \\
\text { Culture }\end{array}$ & 0.696 & 0.625 & 0.700 & 0.477 & 0.806 & & \\
\hline $\begin{array}{c}\text { Process } \\
\text { Management }\end{array}$ & 0.578 & 0.486 & 0.557 & 0.458 & 0.637 & 0.952 & \\
\hline $\begin{array}{l}\text { Strategic } \\
\text { Planning }\end{array}$ & 0.581 & 0.500 & 0.558 & 0.482 & 0.723 & 0.549 & 0.866 \\
\hline
\end{tabular}

Table 8. Heterotrait-Monotrait Ratio (HTMT).

\begin{tabular}{|c|c|c|c|c|c|c|c|}
\hline Variable & $\begin{array}{c}\text { Corporate } \\
\text { Green } \\
\text { Performance }\end{array}$ & $\begin{array}{l}\text { Customer } \\
\text { Focus }\end{array}$ & $\begin{array}{c}\text { Human } \\
\text { Resource } \\
\text { Management }\end{array}$ & $\begin{array}{l}\text { Information } \\
\text { and Analysis }\end{array}$ & $\begin{array}{c}\text { Organizational } \\
\text { Culture }\end{array}$ & $\begin{array}{c}\text { Process } \\
\text { Management }\end{array}$ & $\begin{array}{l}\text { Strategic } \\
\text { Planning }\end{array}$ \\
\hline \multicolumn{8}{|l|}{ Corporate } \\
\hline \multicolumn{8}{|l|}{ Performance } \\
\hline $\begin{array}{l}\text { Customer } \\
\text { Focus } \\
\text { Human }\end{array}$ & 0.689 & & & & & & \\
\hline Resource & 0.832 & 0.731 & & & & & \\
\hline Management & & & & & & & \\
\hline $\begin{array}{l}\text { Information } \\
\text { and Analysis }\end{array}$ & 0.616 & 0.631 & 0.779 & & & & \\
\hline $\begin{array}{c}\text { Organizational } \\
\text { Culture }\end{array}$ & 0.774 & 0.697 & 0.796 & 0.531 & & & \\
\hline $\begin{array}{c}\text { Process } \\
\text { Management }\end{array}$ & 0.642 & 0.540 & 0.638 & 0.510 & 0.713 & & \\
\hline $\begin{array}{l}\text { Strategic } \\
\text { Planning }\end{array}$ & 0.639 & 0.551 & 0.626 & 0.531 & 0.794 & 0.600 & \\
\hline
\end{tabular}

\subsection{The Structure Model and Hypotheses Testing}

The structural model measures the relationship between the given variables of a study. It is nothing more than the regression analysis. Figure 4 shows the results of the structure model that includes a beta value which reflects the value of the impact of the explanatory variables on the dependent variable. The sign with the beta value shows the direction of the impact. The structure model also provides $t$-value and $p$-value. These values are used to measure the significance of the relationship. For a significant relationship, $t$-value must be greater \pm 1.96 or $p$-value needs to be less than 0.05 . Signs with $t$-value also show the direction of the relationship, just like a sign with the beta value. The structure model results also include the value of $R^{2}$, which shows the strength of the relationship. These values have importance when we want to predict the future on the basis of the study result following Frost [143]. 


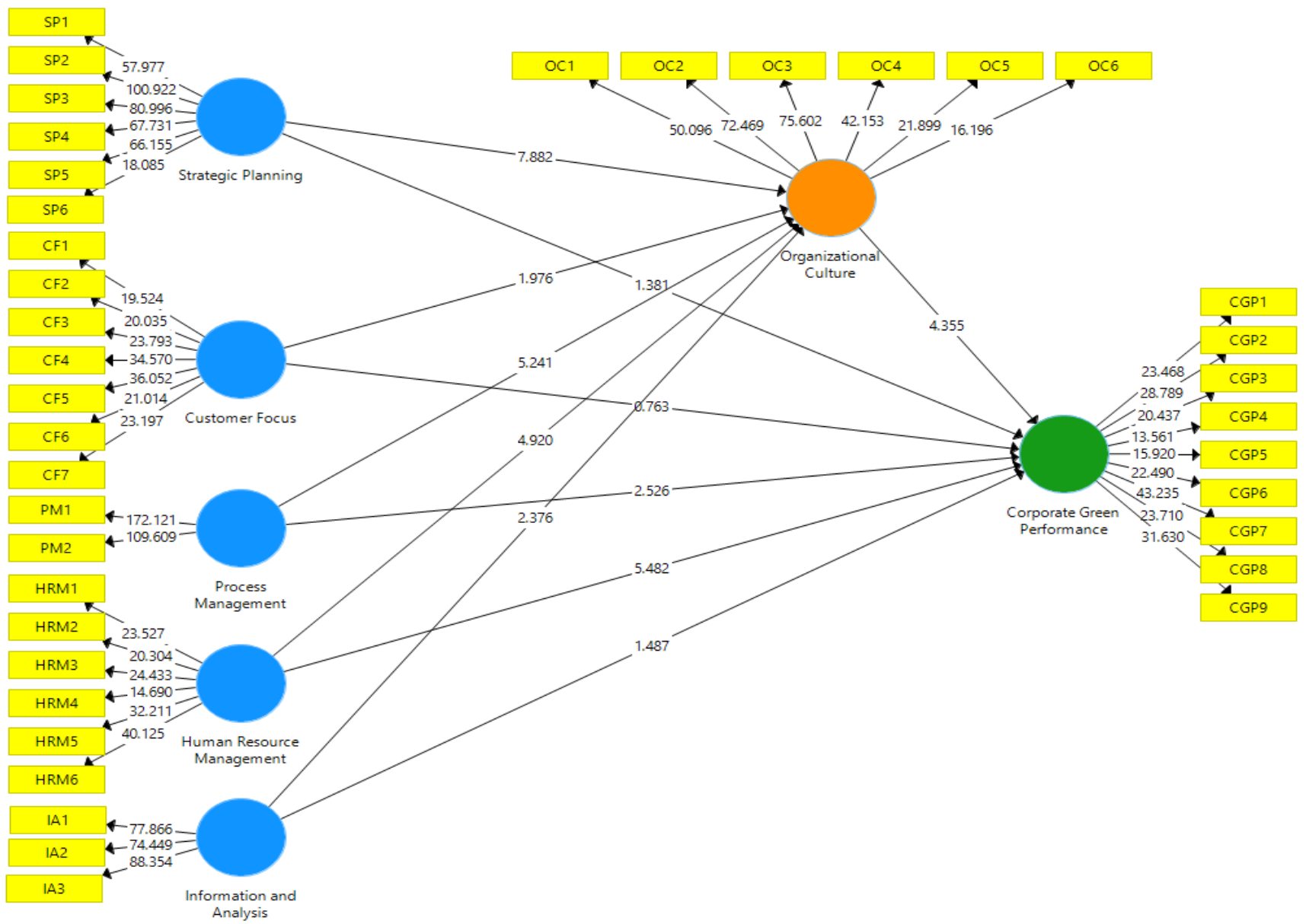

Figure 4. The Structure Model.

This study was based on six main hypotheses which have direct relationships, and only two hypotheses were not accepted out of the six hypotheses. For instance, SP has a significant effect on CGP $(p=0.00, \beta=0.176, t$-value $=4.381)$, and the hypothesis H1 is supported. Likewise, SP positively influences OC $(p=0.00, \beta=0.413, t$-value $=7.882)$ and this validated the second hypothesis (H1a). However, the CF does not affect CGP ( $p>0.05$, $\beta=0.040, t$-value $=0.763$ ) and the third hypothesis $\mathrm{H} 2$ is not supported. Though, CF has a positive influence on OC $(p=0.049, \beta=0.107, t$-value $=1.976)$ and endorsed the hypothesis H2a. PM also positively affects CGP $(p=0.012, \beta=0.119, t$-value $=2.526)$ and thus we have accepted the third main hypothesis H3. Furthermore, the PM positively influenced OC $(p=0.00, \beta=0.222, t$-value $=5.241)$ and this supported the hypothesis H3a. HRM has a positive impact on CGP $(p=0.00, \beta=0.392, t$-value $=5.482)$ and this supported the fourth hypothesis H4. The HRM positively influenced OC $(p=0.00, \beta=0.324, t$-value $=4.920)$ and this supported the hypothesis H4a. Meanwhile, IA has no impact on CGP ( $p>0.05$, $\beta=0.067, t$-value $=1.487)$, and so the fifth hypothesis $(\mathrm{H} 5)$ is not validated. However, IA positively impacts OC $(p=0.018, \beta=0.095, t$-value $=2.376)$ and so we have accepted the hypothesis H5a. Similarly, OC has a definite impact on CGP $(p=0.00, \beta=0.233$, $t$-value $=4.355)$ and this supported the hypothesis H6. The results demonstrate below in Table 9. 
Table 9. Direct Hypothesis Testing Results.

\begin{tabular}{cccccccc}
\hline Hypotheses & Constructs & Original Sample & Sample Mean & Standard Deviation & $t$-Values & $p$-Values & Results \\
\hline H1 & SP - > CGP & 0.176 & 0.075 & 0.055 & 4.381 & 0.000 & Accepted \\
H1a & SP -> OC & 0.413 & 0.410 & 0.052 & 7.882 & 0.000 & Accepted \\
H2 & CF - > CGP & 0.040 & 0.041 & 0.053 & 0.763 & 0.446 & Rejected \\
H2a & CF -> OC & 0.107 & 0.107 & 0.054 & 1.976 & 0.049 & Accepted \\
H3 & PM -> CGP & 0.119 & 0.122 & 0.047 & 2.526 & 0.012 & Accepted \\
H3a & PM -> OC & 0.222 & 0.225 & 0.042 & 5.241 & 0.000 & Accepted \\
H4 & HRM - CGP & 0.392 & 0.394 & 0.072 & 5.482 & 0.000 & Accepted \\
H4a & HRM -> OC & 0.324 & 0.321 & 0.066 & 4.920 & 0.000 & Accepted \\
H5 & IA -> CGP & 0.067 & 0.064 & 0.045 & 1.487 & 0.138 & Rejected \\
H5a & IA -> OC & 0.095 & 0.093 & 0.040 & 2.376 & 0.018 & Accepted \\
H6 & OC - CGP & 0.233 & 0.232 & 0.053 & 4.355 & 0.000 & Accepted \\
\hline
\end{tabular}

\subsection{Mediation Testing}

According to the proposed model of this study, the organizational culture was used as a mediating variable. To assess whether this mediation impact strengthens or weakens the relationship between the independent and dependent variables, and to see its influence, we can refer to the results of the indirect effects of the model and compare these results to the direct effects. According to the results shown in Table 10, organizational culture plays a significant part in positively influencing the relationship. OC plays a positive mediating role between SP, CF, PM, HRM, IA, and CGP. OC positively and significantly mediated the relationship between SP and CGP $(p=0.00, \beta=0.096, t$-value $=4.023$,$) and$ this validated the hypothesis H1b. However, OC has no significant mediation impact in the relationship between CF and CGP $(p>0.05, \beta=0.025, t$-value $=1.618)$ and $\mathrm{H} 2 \mathrm{~b}$ is therefore not supported. Furthermore, OC significantly and positively mediates the relationship among the PM and CGP $(p=0.002, \beta=0.052, t$-value $=3.174)$ and this validates H3b. Likewise, OC positively mediates the relationship between HRM and CGP ( $p=0.00$, $\beta=0.075, t$-value $=3.636$ ) and this has supported H4b. Moreover, IA has no influence on CGP except in the presence of OC, and this relationship boosted the impact $(p=0.021$, $\beta=0.022, t$-value $=2.211$ ) and so confirmed H5b.

Table 10. Indirect Hypotheses Testing Results.

\begin{tabular}{|c|c|c|c|c|c|c|c|}
\hline Hypotheses & Constructs & Original Sample & Sample Mean & Standard Deviation & $t$ Values & $p$ Values & Results \\
\hline $\mathrm{H} 1 \mathrm{~b}$ & SP $\rightarrow>$ OC $\rightarrow$ CGP & 0.096 & 0.095 & 0.024 & 4.023 & 0.000 & Accepted \\
\hline $\mathrm{H} 2 \mathrm{~b}$ & $\mathrm{CF}->\mathrm{OC}->\mathrm{CGP}$ & 0.025 & 0.026 & 0.015 & 1.618 & 0.106 & Rejected \\
\hline $\mathrm{H} 3 \mathrm{~b}$ & $\mathrm{PM}->\mathrm{OC} \rightarrow \mathrm{CGP}$ & 0.052 & 0.052 & 0.016 & 3.174 & 0.002 & Accepted \\
\hline $\mathrm{H} 4 \mathrm{~b}$ & HRM $->$ OC $->$ CGP & 0.075 & 0.074 & 0.021 & 3.636 & 0.000 & Accepted \\
\hline $\mathrm{H} 5 \mathrm{~b}$ & $\mathrm{IA} \rightarrow>\mathrm{OC} \rightarrow \mathrm{CGP}$ & 0.022 & 0.021 & 0.010 & 2.211 & 0.027 & Accepted \\
\hline
\end{tabular}

\subsection{The Predictive Relevance of the Model}

In the present research, two factors are verified with $R$ square and cross-validated redundancy to assess the model's predictive relevance. $R$ square values mean that the endogenous variable is explained jointly by all exogenous variables. Table 11 demonstrates that all independent variables describe $68.8 \%$ of OC, whereas $62.8 \%$ of CGP is illustrated by all independent variables. An $R$ square value in the range of 0.02 to 0.13 shows weak or small explanation, the $R$ square value in the array of 0.13 to 0.26 is moderate, and $R$ square value greater than 0.26 indicates that the explanation is highly efficient [100]. As Table 10 shows, the $R$ square value for CGP and OC indicates a strong effect. The cross-validated redundancy is measured by running blindfolding in PLS tools. According to some prior researchers, the value of $Q^{2}$ must be more than zero [142,144-147]. Table 12 reveals that the $Q^{2}$ value of CGP and OC fulfils the abovementioned required criteria. 
Table 11. The predictive relevance of study model.

\begin{tabular}{ccc}
\hline Total & $R$ Square & Assessment \\
\hline Corporate Green Performance & 0.628 & Good \\
Organizational Culture & 0.688 & Good \\
\hline
\end{tabular}

Table 12. Cross-validated redundancy.

\begin{tabular}{cccc}
\hline Total & SSO & SSE & $Q^{\mathbf{2}}$ (=1-SSE/SSO) \\
\hline Corporate Green Performance & 3321.000 & 2262.748 & 0.319 \\
Organizational Culture & 2214.000 & 1252.750 & 0.434 \\
\hline
\end{tabular}

\subsection{Model Fit}

The standardized root means squared residuals (SRMR) shows an approximate fit of the model. It captures the magnitude of how the model's implied correlation matrix is differed with the observed correlation matrix and provides an estimate of the average magnitude of these differences. The lower the value of SRMR, the better a model fit is. A model is considered to have a good fit if the SRMR is less than or equal to $0.08[137,148]$. Some researchers follow a softer point of SRMR value of less than 0.10 . The value of the SRMR of the model in this study is 0.068 . This value confirms that the model is correctly specified and can be considered as acceptable. Therefore, the model meets the criteria of being fit in terms of its SRMR value.

\section{Discussion}

The present research seeks to examine the impact of total quality management practices on corporate green performance via organizational culture mediation. The data was collected from medium and large private hospitals situated in six major commercial cities in Pakistan, including Karachi, Lahore, Multan, Islamabad, Peshawar, and Faisalabad via personal visits. The data was congregated from management personnel at the lower, middle, and upper levels, providing detailed insights and information about firms' practices and policies. In addition, they are also the key people in their organizations who exchange data and enforce organizational policies. The researchers used SmartPLS software for data analysis. The findings have revealed a positive and significant impact of TQM on CGP. As per the structure model, results also indicated that three out of five TQM practices, namely strategic planning $(\mathrm{H} 1)$, process management $(\mathrm{H} 3)$, and human resource management $(\mathrm{H} 4)$ have a positive and significant impact on CGP through the acceptable values of $p$, $\beta$, and $t$. Therefore, the hypotheses H1, H3, and H4 stand supported (see Table 9 and Figure 4). These findings confirm studies by Abbass [13] and Green et al. [38], who found the significant and positive influence of total quality management on corporate green management performance in context of supply chain management. However, two out of five dimensions, namely customer focus (H2) and information and analysis (H5), negatively influence CGP with their non-significant values following the structural equation model. Hence, the hypotheses $\mathrm{H} 2$ and $\mathrm{H} 5$ are not supported. The negative relationship is not surprising, as it is observed that the health sector's major focus might be on inside practices and operations of organization, such as strategic planning, process management, and human resource management, which are their main priority while the concept of green performance is at the understanding stage in Pakistan. Therefore, these results are comparable to Li et al. [4] and Suleman \& Gul [149], who concluded that there was a negative link between corporate green innovation and total quality management practices in Chinese manufacturing firms. Bearing in mind TQM's ideology of customer focus and continuous improvement, organizations typically follow quality management strategies to enhance the efficiency of existing goods and services to meet customer and stakeholder demands. Since the whole process is almost under control in the TQM system to evade deviations and defects, this structure can discourage businesses from innovation [4]. Based on the current study outcomes, it 
can be clearly said that the sampled companies are efficiently capitalizing on TQM, which helps them to increase their green performance.

There are several interrelated factors, such as top management engagement, technological knowledge, infrastructure, and capitalization on the modern technologies, which depend on the successful implementation of TQM practices and the achievement of CGP goals, that could be a main reason for the significant and constructive relationship between TQM practices and CGP. The incorporation of the new technologies with TQM helps companies to turn their conventional processes into green processes [4,13]. By following TQM practices, companies can boost their employees' knowledge and abilities regarding the effective utilization of resources. Employees are more empowered and motivated when working in an environment that ensures that their goods and services serve exceptional quality to society and protect the natural environment. This study suggests that if a firm can manage its TQM activities effectively, it will enhance the skills, abilities, and level of motivation of the employees to use the resources in productive ways, resulting in augmented CGP.

Total quality management practices with positive values have also been shown to have a positive and significant influence on OC. Therefore, strategic planning (H1a), customer focus $(\mathrm{H} 2 \mathrm{a})$, process management $(\mathrm{H} 3 \mathrm{a})$, human resource management $(\mathrm{H} 4 \mathrm{a})$, and information and analysis (H5a) are supported. These findings are related to Eniola et al.'s [150] work, which found that an organized TQM program and practices enhance firm culture and skills. These results are also consistent with Baird et al. [151], who demonstrated that there was a positive relationship between OC and TQM practices. This substantial result indicates that if a firm can effectively handle its TQM practices, it will heighten its culture and skills to perform and contribute accordingly. This substantial result demonstrates that the target sampled private hospitals are effectively relying on TQM practices to attain perfection in the development of OC and TQM, drastically encouraging companies' competencies to perform its starring role in the development of culture. Another interesting finding from the current study is that OC is positively associated with CGP ( $p=0.05$, $\beta=0.233$, $t$-value $=4.355$ ), so H6 is also accepted. The recognition of this relationship extends Yu and Choi [30]'s finding that OC significantly influences the CGP.

\subsection{Practical and Theoretical Implications}

The current research has several implications from a managerial and theoretical viewpoint. From the industrial view, the abovementioned results show that TQM practices are significant to attaining CGP goals in the health sector. These results also explain the vital role of organizational culture in accomplishing CGP goals, and shows that through assimilating TQM and OC practices, an organization can accomplish perfection in day-today operations and lead themselves towards strategic and competitive advantage. The structural analysis values reveal that CGP objectives are directly linked to the effective implementation of TQM and OC practices. Organizations which actively play a part in societal development programs and effectively engaged with quality management activities are able to outpace the followers of conventional practices. For this purpose, organizations should commit to the effective implementation of TQM practices by adopting some quality program to accomplish CGP goals, such as Kaizen, EFQM, and MBNQA. Further, most previous studies that examine the impact of the contextual factors on TQM implementation consider TQM as a single factor without giving consideration to the possible different impacts on the different dimensions that TQM embodies. The findings in this study also address this concern by demonstrating that the organizational factors have different relationships with different dimensions of TQM. While centralization of authority can facilitate the implementation of TQM practices, it also impedes the implementation of both soft and hard QM practices. Further studies need to give more attention to the different dimensions of TQM as it is subject to the influence of contextual factors. 
The results reported here argue that TQM practices are linked with supporting OC practices that are necessary for the enhancement of green performance in the health sector and introduce TQM practices as an antecedent for improved corporate culture and CGP in such sectors. This also theorizes for the first time that TQM goals of reduced waste, defects, and enhanced resource consumption are closely paralleled with quality and environmentally friendly practices in the health sector. Furthermore, the positive impact of OC on CGP has not been explored previously in this context, which serves as another key contribution by enriching existing green performance literature in the context of developing countries. This also helps in answering the question "does it pay to be green?" posed by several researchers in CGP literature, e.g., Hart and Ahuja [152], Berchicci and King [153], and Afum et al. [154]. The current study also validates arguments about achieving enhancements in private hospitals' CGP in an efficient manner by the implementation of TQM in the context of developing countries. In addition, this research supports the argument that OC mediation affects the relationship between TQM and CGP in the health sector. To the best of the authors' knowledge, this mediation effect has not been previously investigated in previous TQM and green performance studies performed in Pakistan, thus adding another key contribution to knowledge in TQM practices and green performance.

The current study also illustrates that TQM is essential for both large and mediumsized hospitals, which means that if medium-sized businesses adopt TQM successfully, regardless of hospital size, it may encourage the attainment of CGP goals. Thus, this study gives the management of medium-sized businesses trust that they can gain the same advantages from TQM as large firms. The current study also indicates that the positive influence of TQM activities is not limited exclusively to businesses operating in developed countries. If organizations successfully apply TQM activities in developing or under-developed countries, parallel results can also be obtained.

From a theoretical point of view, current research enriches in various ways the available literature on TQM, OC, and CGP. First, this research bridges the literature gap on the TQM-CGP relationship, especially in Pakistani hospitals. This research also supports the TQM proponents' claims that successful TQM implementation can dramatically improve organizational efficiency. Secondly, this study validates the green theory, institutional theory, MBNQA, and CGP models, and explores the conceptual model's robustness via the structure model, something which has hardly been carried out in prior studies. Lastly, this research shows OC's function, which positively mediates the relationship between TQM and CGP, which has also rarely been estimated before.

\subsection{Limitation and Future Direction}

The present study also has certain limitations similar to other research. The researchers collected the data by requesting the respondents to conceptualize the questionnaire based on the firm's actual output; therefore, this caused bias in the collected responses because it was purely based on respondents' perceptions. Though the reliability and validity have been thoroughly analyzed, it is impossible to rule out the impact of biases completely. Therefore, the firms' secondary data can also be beneficial in terms of extra evidence related to the relationships between TQM, OC, and CGP. Moreover, due to the spread of COVID19 , the researchers faced many constraints during the data collection phase in terms of accessibility and response rate. Secondly, the target market for data collection was based on only six cities' private hospitals. The area of the study should be broadened to include other big cities and countries. Likewise, the lower-, middle-, and upper-level management was targeted for data collection, and this ignored the operational staff, whose view might provide more insights. Hence, the researcher can take their perception in future while further studying these factors. 


\section{Conclusions}

Bearing in mind the environmental concern primarily triggered by the hospital sector, the significance of green growth has considerably increased concern for sustainability achievements. For developing countries, green growth has special significance, for example in Pakistan, where this phenomenon is at the introductory level and a developed-countries approach is considered. In recent years, the Pakistani government has made a significant investment in encouraging green business practices. The researchers examined the role of TQM in CGP in the current study and explored how OC mediates the relationship between the two variables. The researchers generated six main hypotheses based on the MBNQA model, institutional theory, green theory, and essential arguments built based on current literature, which were tested through structure modelling. The findings demonstrate that TQM has a significant and positive impact on CGP and has a strong potential to enhance green business practices. In addition, OC significantly mediates the relationship between TQM and CGP. It is also very rare to find previous studies where the mediating effect of firm culture in the health sector is examined in the relationship between TQM practices and the green performance of firms specifically in Pakistan. With the help of OC mediation, the constructive outcomes of TQM in CGP in the Pakistani health sector show that if companies effectively adopt TQM practices, it will enhance CGP even in developing countries. However, government and top-management dedication are imperative to achieving green business goals.

Author Contributions: Conceptualization, M.K.K. and U.M.; methodology, M.K.K. and U.M.; software, M.K.K; validation, M.K.K. and U.M.; formal analysis, M.K.K.; in-vestigation, M.K.K.; resources, M.K.K.; data curation, M.K.K.; writing-original draft preparation, M.K.K.; writing-review and editing, M.K.K.; visualization, U.M.; super-vision, U.M. All authors have read and agreed to the published version of the manuscript.

Funding: This research received no external funding.

Institutional Review Board Statement: Not Applicable.

Informed Consent Statement: Informed consent was obtained from all subjects involved in the study.

Data Availability Statement: Not Applicable.

Acknowledgments: This work was supported by the Higher Education Research Promotion and the Thailand's Education Hub for the Southern Region of ASEAN Countries Project Office of the Higher Education Commission.

Conflicts of Interest: The authors declare no conflict of interest.

Appendix A. Questionnaire

\footnotetext{
Strategic Planning

This hospital has a clear vision and mission statements which are supported by all employees

The top management of this hospital regularly sets and reviews short and long-term goals for managers

The management provides adequate resources and support to achieve short and long-term objectives

The policies and plans of this hospital consider employees', customers', and other stakeholders' needs

The strategies and plans of this hospital are focused on quality improvement

Our hospital's operational activities are effectively aligned with mission and vision statements
} 


\section{Customer Focus \\ This hospital design policies by considering the customers' requirements \\ We regularly provide information about our new policies and services to our customer \\ This hospital regularly takes feedback from customers about their experiences and expectations to measure their satisfaction \\ The information about customers' experience and expectations is widely used by the management to improve the services \\ Managers and executives support the employees' initiatives to improve customers' satisfaction \\ We are keen to resolve customers complaints and have an effective mechanism for it \\ This organization keeps a strong relationship with customers by providing them with an easy channel for communication}

\section{Process Management}

We have standardized operational processes which are clear and well understood by employees and customers

Most of the processes in our organization are automated, fool-proof, and minimizes human error chances

\section{Human Resource Management}

The management gives high value to recruitment and selection standards

My organization regularly arranges training and development sessions for its employees

We have effective work recognition and reward system to motivate the employees

The management of this hospital regularly takes employees' views and consider them to improve product and service quality

We have effective top-to-bottom and bottom-to-top communication process

Quality is taken as their responsibility by all employees

\section{Information \& Analysis}

We have effective information and reporting system for all products and services

The management regularly provides quality data (errors, complains, defects etc.) to the workers

Workers, supervisors, and managers can easily retrieve information about different products and services

Organizational Culture
People I work with function as a team
People I work with accept criticisms without becoming defensive
My supervisor delegates responsibilities
My supervisor gives me criticism in a constructive manner
This hospital motivates people to be efficient and productive
I am asked to make suggestions about how to do my job better

\section{Corporate Green Performance}

The management of this hospital is highly committed to following environment friendly policies

We regularly review and redesign our strategies to ensure its compliance with environmental criteria

This hospital is open to adopting new or improve existing management system with respect to policies and practices

The management of our organization takes initiatives to raise awareness about the environmental issues and impacts of business operations

The building layout of this hospital is environmentally responsible and Eco-friendly

The way-findings of this hospital are resource efficient

The hospital efficiently using energy, water and other resources

The green infrastructure practices aim to reduce the environmental impact of building

The building uses the thermal control to moderate the temperature and reduces the energy consumption for heating and cooling

\section{References}

1. Abbas, J.; Sağsan, M. Impact of knowledge management practices on green innovation and corporate sustainable development: A structural analysis. J. Clean. Prod. 2019, 229, 611-620. [CrossRef]

2. Wijethilake, C. Proactive sustainability strategy and corporate sustainability performance: The mediating effect of sustainability control systems. J. Environ. Manag. 2017, 196, 569-582. [CrossRef]

3. Ji, Q.; Zhang, D. How much does financial development contribute to renewable energy growth and upgrading of energy structure in China? Energy Policy 2019, 128, 114-124. [CrossRef]

4. Li, D.; Zhao, Y.; Zhang, L.; Chen, X.; Cao, C. Impact of quality management on green innovation. J. Clean. Prod. 2018, 170, 462-470. [CrossRef]

5. Sepehri, A.; Sarrafzadeh, M.-H. Effect of nitrifiers community on fouling mitigation and nitrification efficiency in a membrane bioreactor. Chem. Eng. Process. Intensif. 2018, 128, 10-18. [CrossRef] 
6. Fernando, Y.; Jabbour, C.J.C.; Wah, W.-X. Pursuing green growth in technology firms through the connections between environmental innovation and sustainable business performance: Does service capability matter? Resour. Conserv. Recycl. 2019, 141, 8-20. [CrossRef]

7. Davenport, M.; Delport, M.; Blignaut, J.N.; Hichert, T.; Van der Burgh, G. Combining theory and wisdom in pragmatic, scenario-based decision support for sustainable development. J. Environ. Plan. Manag. 2019, 62, 692-716. [CrossRef]

8. Masocha, R. Does environmental sustainability impact innovation, ecological and social measures of firm performance of SMEs? Evidence from South Africa. Sustainability 2018, 10, 3855. [CrossRef]

9. Miroshnychenko, I.; Barontini, R.; Testa, F. Green practices and financial performance: A global outlook. J. Clean. Prod. 2017, 147, 340-351. [CrossRef]

10. Yu, Y.; Huo, B. The impact of environmental orientation on supplier green management and financial performance: The moderating role of relational capital. J. Clean. Prod. 2019, 211, 628-639. [CrossRef]

11. Amores-Salvadó, J.; Martín-de Castro, G.; Navas-López, J.E. Green corporate image: Moderating the connection between environmental product innovation and firm performance. J. Clean. Prod. 2014, 83, 356-365. [CrossRef]

12. Xie, X.; Huo, J.; Zou, H. Green process innovation, green product innovation, and corporate financial performance: A content analysis method. J. Bus. Res. 2019, 101, 697-706. [CrossRef]

13. Abbas, J. Impact of total quality management on corporate green performance through the mediating role of corporate social responsibility. J. Clean. Prod. 2020, 242, 118458. [CrossRef]

14. Zwain, A.A.A.; Lim, K.T.; Othman, S.N. TQM and academic performance in Iraqi HEIs: Associations and mediating effect of KM. TQM J. 2017, 29, 357-368. [CrossRef]

15. Almahamid, S.M.; Qasrawi, S.T. The impact of TQM practices and KM processes on organisational performance. Int. J. Qual. Reliab. Manag. 2017, 34, 1034-1055.

16. Yusr, M.M.; Mokhtar, S.S.M.; Othman, A.R.; Sulaiman, Y. Does interaction between TQM practices and knowledge management processes enhance the innovation performance? Int. J. Qual. Reliab. Manag. 2017, 34, 955-974. [CrossRef]

17. Shafiq, M.; Lasrado, F.; Hafeez, K. The effect of TQM on organisational performance: Empirical evidence from the textile sector of a developing country using SEM. Total Qual. Manag. Bus. Excell. 2019, 30, 31-52. [CrossRef]

18. Hollingworth, D.; Valentine, S. Corporate social responsibility, continuous process improvement orientation, organizational commitment and turnover intentions. Int. J. Qual. Reliab. Manag. 2014, 31, 629-651. [CrossRef]

19. Pettigrew, A.M. On studying organizational cultures. Adm. Sci. Q. 1979, 24, 570-581. [CrossRef]

20. Schwartz, H.; Davis, S.M. Matching corporate culture and business strategy. Organ. Dyn. 1981, 10, 30-48. [CrossRef]

21. Silverzweig, S.; Allen, R.F. Changing the corporate culture. Sloan Manag. Rev. 1976, 17, 33.

22. Xenikou, A.; Furnham, A. A correlational and factor analytic study of four questionnaire measures of organizational culture. Hum. Relations 1996, 49, 349-371. [CrossRef]

23. Siehl, C.; Martin, J. Measuring organizational culture: Mixing qualitative and quantitative methods. In Inside Organizations: Understanding the Human Dimension; Sage Publication: New York, NY, USA, 1988; pp. 79-104.

24. Cooke, F.L.; He, Q. Corporate social responsibility and HRM in China: A study of textile and apparel enterprises. Asia Pacific Bus. Rev. 2010, 16, 355-376. [CrossRef]

25. Beer, M.; Nohria, N. Cracking the code of change. HBR's 10 Must Reads Chang. 2000, 78, 133-141.

26. Mintzberg, H. The effective organization: Forces and forms. Sloan Manag. Rev. 1991, 32, 54-67.

27. Hofstede, G.H.; Hofstede, G.J.; Minkov, M. Cultures and Organizations: Software of the Mind; Mcgraw-hill: New York, NY, USA, 2005; Volume 2.

28. Gelaidan, H.M.; Ahmad, H. The factors effecting employee commitment to change in public sector: Evidence from Yemen. Int. Bus. Res. 2013, 6, 75-87. [CrossRef]

29. Kanter, R.M. Transforming giants. Harv. Bus. Rev. 2008, 86, 43.

30. Yu, Y.; Choi, Y. Stakeholder pressure and CSR adoption: The mediating role of organizational culture for Chinese companies. Soc. Sci. J. 2016, 53, 226-234. [CrossRef]

31. Cameron, K.S.; Quinn, R.E. Diagnosing and Changing Organizational Culture: Based on the Competing Values Framework; John Wiley \& Sons: Hoboken, NJ, USA, 2011.

32. Quazi, A.M. Identifying the determinants of corporate managers' perceived social obligations. Manag. Decis. 2003, $41,822-831$. [CrossRef]

33. Galbreath, J. Drivers of corporate social responsibility: The role of formal strategic planning and firm culture. Br. J. Manag. 2010, 21, 511-525. [CrossRef]

34. Kalyar, M.N.; Rafi, N.; Kalyar, A.N. Factors affecting corporate social responsibility: An empirical study. Syst. Res. Behav. Sci. 2013, 30, 495-505. [CrossRef]

35. Linnenluecke, M.K.; Griffiths, A. Corporate sustainability and organizational culture. J. World Bus. 2010, 45, 357-366. [CrossRef]

36. Carroll, A.B.; Shabana, K.M. The business case for corporate social responsibility: A review of concepts, research and practice. Int. J. Manag. Rev. 2010, 12, 85-105. [CrossRef] 
37. Lubis, A.N.; Lumbanraja, P.; Lubis, R.R.; Hasibuan, B.K. A study of service quality, corporate social responsibility, hospital image, and hospital value creation in Medan. Eur. Res. Stud. J. 2017, 20, 125-133.

38. Green, K.W.; Inman, R.A.; Sower, V.E.; Zelbst, P.J. Impact of JIT, TQM and green supply chain practices on environmental sustainability. J. Manuf. Technol. Manag. 2019, 30, 26-47. [CrossRef]

39. Huang, J.-W.; Li, Y.-H. Green innovation and performance: The view of organizational capability and social reciprocity. J. Bus. Ethics 2017, 145, 309-324. [CrossRef]

40. Wang, C.-H. How organizational green culture influences green performance and competitive advantage. J. Manuf. Technol. Manag. 2019, 30, 666-683. [CrossRef]

41. Tasleem, M.; Khan, N.; Nisar, A. Impact of total quality management and environmental management system on sustainable performance of selected industries in Pakistan. J. Environ. Sci. Manag. 2018, 21, 30-38.

42. Shahzad, M.; Qu, Y.; Ur Rehman, S.; Zafar, A.U.; Ding, X.; Abbas, J. Impact of knowledge absorptive capacity on corporate sustainability with mediating role of CSR: Analysis from the Asian context. J. Environ. Plan. Manag. 2020, 63, 148-174. [CrossRef]

43. Zhang, D.; Rong, Z.; Ji, Q. Green innovation and firm performance: Evidence from listed companies in China. Resour. Conserv. Recycl. 2019, 144, 48-55. [CrossRef]

44. Adil, M.S. Impact of leader's change-promoting behavior on readiness for change: A mediating role of organizational culture. J. Manag. Sci. 2014, 1, 102-123.

45. Singh, V.; Kumar, A.; Singh, T. Impact of TQM on organisational performance: The case of Indian manufacturing and service industry. Oper. Res. Perspect. 2018, 5, 199-217. [CrossRef]

46. UNGC. United Nations Global Compact; United Nations: New York, NY, USA, 2018.

47. Raimi, L. Understanding theories of corporate social responsibility in the Ibero-American hospitality industry. In Corporate Social Responsibility and Corporate Governance; Emerald Publishing Limited: Bingley, West Yorkshire, UK, 2017.

48. Eckersley, R. Green Theory in International Relations Theories: Discipline and Diversity; Oxford University Press: New York, NY, USA, 2010; Volume 10, pp. 70200-70202.

49. Cancino, C.A.; La Paz, A.I.; Ramaprasad, A.; Syn, T. Technological innovation for sustainable growth: An ontological perspective. J. Clean. Prod. 2018, 179, 31-41. [CrossRef]

50. Rekik, L.; Bergeron, F. Green Practice Motivators and Performance in SMEs: A Qualitative Comparative Anaysis. J. Small Bus. Strateg. 2017, 27, 1-18.

51. Yuan, B.; Xiang, Q. Environmental regulation, industrial innovation and green development of Chinese manufacturing: Based on an extended CDM model. J. Clean. Prod. 2018, 176, 895-908. [CrossRef]

52. Lounsbury, M. Institutional rationality and practice variation: New directions in the institutional analysis of practice. Account. Organ. Soc. 2008, 33, 349-361. [CrossRef]

53. Johansson, T.; Siverbo, S. Why is research on management accounting change not explicitly evolutionary? Taking the next step in the conceptualisation of management accounting change. Manag. Account. Res. 2009, 20, 146-162. [CrossRef]

54. Seo, M.-G.; Creed, W.E.D. Institutional contradictions, praxis, and institutional change: A dialectical perspective. Acad. Manag. Rev. 2002, 27, 222-247. [CrossRef]

55. Beckert, J. Agency, entrepreneurs, and institutional change. The role of strategic choice and institutionalized practices in organizations. Organ. Stud. 1999, 20, 777-799. [CrossRef]

56. Khalil, M.A.; Nimmanunta, K. Conventional versus green investments: advancing innovation for better financial and environmental prospects. J. Sustain. Financ. Investig. 2021, 1-28. [CrossRef]

57. Ma, Y.; Hou, G.; Xin, B. Green process innovation and innovation benefit: The mediating effect of firm image. Sustainability 2017, 9, 1778. [CrossRef]

58. Abbas, J.; Mahmood, H.K.; Hussain, F. Information security management for small and medium size enterprises. Sci. Int. 2015, $27,2393-2398$.

59. USGBC. LEED 2009 for Healthcare; U.S. Green Building Council: Washington, DC, USA, 2011.

60. Mahmood, H.K.; Hashmi, M.S.; Shoaib, M.; Danish, R.; Abbas, J. Impact of TQM practices on motivation of teachers in secondary schools empirical evidence from Pakistan. J. Basic Appl. Sci. Res. 2014, 4, 1-8.

61. Deming, W.E. Out of the Crisis; Massachusetts Institute of Technology, Center for Advanced Engineering Study: Cambridge, MA, USA, 1986.

62. Madu, C.N. Strategic total quality management. In Handbook of Total Quality Management; Springer: Berlin/Heidelberg, Germany, 1998; pp. 165-212.

63. Kiran, D.R. Total Quality Management: Key Concepts and Case Studies; Butterworth-Heinemann: London, UK, 2016.

64. Ahmad, M.F.; Zakuan, N.; Jusoh, A.; Yusof, S.M.; Takala, J.; Arif, M.S.M. Comparative study of TQM practices between Japanese and non-Japanese companies: Proposed conceptual framework. In Proceedings of the Advanced Materials Research; Trans Tech Publications Ltd.: Bäch, Switzerland, 2014; Volume 903, pp. 371-377. [CrossRef]

65. Witcher, B. The adoption of total quality management in Scotland. TQM Mag. 1994, 6, 48-53. [CrossRef]

66. Leung, H.K.N.; Chan, K.C.C.; Lee, T.Y. Costs and benefits of ISO 9000 series: A practical study. Int. J. Qual. Reliab. Manag. 1999, 16, 675-691. [CrossRef]

67. Jung, J.Y.; Wang, Y.J. Relationship between total quality management (TQM) and continuous improvement of international project management (CIIPM). Technovation 2006, 26, 716-722. [CrossRef] 
68. Abdullah, A. Measuring TQM implementation: A case study of Malaysian SMEs. Meas. Bus. Excell. 2010, 14, 3-15. [CrossRef]

69. Goh, P.L.; Ridgway, K. The implementation of total quality management in small and medium-sized manufacturing companies. TQM Mag. 1994, 6, 54-60. [CrossRef]

70. Hackman, J.R.; Wageman, R. Total quality management: Empirical, conceptual, and practical issues. Adm. Sci. Q. 1995, 309-342. [CrossRef]

71. Kanji, G.K. Total quality management: The second industrial revolution. Total Qual. Manag. 1990, 1, 3-12. [CrossRef]

72. Berry, T.H. Managing the Total Quality Transformation; McGraw-Hill: New York, NY, USA, 1991.

73. Dahlgaard, J.J.; Khanji, G.K.; Kristensen, K. Fundamentals of Total Quality Management; Routledge: England, UK, 2008.

74. Wilkinson, A.; Witcher, B. Holistic total quality management must take account of political processes. Total Qual. Manag. 1993, 4, 47-56. [CrossRef]

75. Kaynak, H. The relationship between total quality management practices and their effects on firm performance. J. Oper. Manag. 2003, 21, 405-435. [CrossRef]

76. Psomas, E.; Vouzas, F.; Kafetzopoulos, D. Quality management benefits through the "soft" and "hard" aspect of TQM in food companies. TQM J. 2014, 26, 431-444. [CrossRef]

77. Fotopoulos, C.B.; Psomas, E.L. The impact of "soft" and "hard" TQM elements on quality management results. Int. J. Qual. Reliab. Manag. 2009, 26, 150-163. [CrossRef]

78. Zeng, J.; Zhang, W.; Matsui, Y.; Zhao, X. The impact of organizational context on hard and soft quality management and innovation performance. Int. J. Prod. Econ. 2017, 185, 240-251. [CrossRef]

79. Vouzas, F.; Psychogios, A.G. Assessing managers' awareness of TQM. TQM Mag. 2007, 19, 62-75. [CrossRef]

80. Prajogo, D.I.; Sohal, A.S. The relationship between organization strategy, total quality management (TQM), and organization performance-The mediating role of TQM. Eur. J. Oper. Res. 2006, 168, 35-50. [CrossRef]

81. Nair, A. Meta-analysis of the relationship between quality management practices and firm performance-implications for quality management theory development. J. Oper. Manag. 2006, 24, 948-975. [CrossRef]

82. Gallardo-Vázquez, D.; Sanchez-Hernandez, M.I. Measuring Corporate Social Responsibility for competitive success at a regional level. J. Clean. Prod. 2014, 72, 14-22. [CrossRef]

83. Lindgreen, A.; Swaen, V.; Maon, F.; Andersen, M.; Skjoett-Larsen, T. Corporate social responsibility in global supply chains. Supply Chain Manag. Int. J. 2009, 14, 75-86.

84. Kannan, V.R.; Tan, K.C. Just in time, total quality management, and supply chain management: Understanding their linkages and impact on business performance. Omega 2005, 33, 153-162. [CrossRef]

85. Fuentes, M.M.F.; Montes, F.J.L.; Fernández, L.M.M. Total quality management, strategic orientation and organizational performance: The case of Spanish companies. Total Qual. Manag. Bus. Excell. 2006, 17, 303-323. [CrossRef]

86. Ahire, S.L.; Dreyfus, P. The impact of design management and process management on quality: An empirical investigation. J. Oper. Manag. 2000, 18, 549-575. [CrossRef]

87. Cua, K.O.; McKone, K.E.; Schroeder, R.G. Relationships between implementation of TQM, JIT, and TPM and manufacturing performance. J. Oper. Manag. 2001, 19, 675-694. [CrossRef]

88. Flynn, B.B.; Schroeder, R.G.; Sakakibara, S. The impact of quality management practices on performance and competitive advantage. Decis. Sci. 1995, 26, 659-691. [CrossRef]

89. Wilson, D.D.; Collier, D.A. An empirical investigation of the Malcolm Baldrige National Quality Award causal model. Decis. Sci. 2000, 31, 361-383. [CrossRef]

90. Pham, T. On the relationship between total quality management practices and firm performance in Vietnam: The mediating role of non-financial performance. Manag. Sci. Lett. 2020, 10, 1743-1754. [CrossRef]

91. Anderson, J.C.; Rungtusanatham, M.; Schroeder, R.G.; Devaraj, S. A path analytic model of a theory of quality management underlying the Deming management method: Preliminary empirical findings. Decis. Sci. 1995, 26, 637-658. [CrossRef]

92. Choi, T.Y.; Eboch, K. The TQM paradox: Relations among TQM practices, plant performance, and customer satisfaction. J. Oper. Manag. 1998, 17, 59-75. [CrossRef]

93. Al-Bishari, K.; Khalil, R. Exploring the Efficiency of E-Tendering Services in Oman: Administrative Perspectives from Government and Business Users. In Sustainable Production and Consumption Systems; Springer: New York, NY, USA; Singapore, 2021; pp. 157-189.

94. Hendricks, K.B.; Singhal, V.R. Quality awards and the market value of the firm: An empirical investigation. Manag. Sci. 1996, 42, 415-436. [CrossRef]

95. Easton, G.S.; Jarrell, S.L. The effects of total quality management on corporate performance: An empirical investigation. J. Bus. 1998, 71, 253-307. [CrossRef]

96. Douglas, T.J.; Judge Jr, W.Q. Total quality management implementation and competitive advantage: The role of structural control and exploration. Acad. Manag. J. 2001, 44, 158-169.

97. Mohrman, S.A.; Tenkasi, R.V.; Lawler, E.E.; Ledford, G.E. Total quality management: Practice and outcomes in the largest US firms. Empl. Relat. 1995, 17, 26-41. [CrossRef]

98. Sánchez-Rodríguez, C.; Martínez-Lorente, Á.R. Quality management practices in the purchasing function: An empirical study. Int. J. Oper. Prod. Manag. 2004, 26, 666-687. [CrossRef] 
99. Dow, D.; Samson, D.; Ford, S. Exploding the myth: Do all quality management practices contribute to superior quality performance? Prod. Oper. Manag. 1999, 8, 1-27. [CrossRef]

100. Shah, R.; Ward, P.T. Lean manufacturing: Context, practice bundles, and performance. J. Oper. Manag. 2003, 21, 129-149. [CrossRef]

101. Tata, J.; Prasad, S.; Motwani, J. Benchmarking quality management practices: US versus Costa Rica. Multinatl. Bus. Rev. 2000, 8 , 37.

102. Carter, J.R.; Narasimhan, R. The role of purchasing and materials management in total quality management and customer satisfaction. Int. J. Purch. Mater. Manag. 1994, 30, 2-13. [CrossRef]

103. Yap, S.F.; Kew, M.L. Service quality and customer satisfaction: Antecedents of customer's re-patronage intentions. Sunw. Acad. J. 2007, 4, 59-73.

104. Khurshid, M.A.; Amin, M.; Ismail, W.K.W. Total quality and socially responsible management (TQSR-M). Benchmarking Int. J. 2018, 25, 2566-2588. [CrossRef]

105. Rahman, S.; Bullock, P. Soft TQM, hard TQM, and organisational performance relationships: An empirical investigation. Omega 2005, 33, 73-83. [CrossRef]

106. Yang, J.; Wong, C.W.Y.; Lai, K.; Ntoko, A.N. The antecedents of dyadic quality performance and its effect on buyer-supplier relationship improvement. Int. J. Prod. Econ. 2009, 120, 243-251. [CrossRef]

107. York, K.M.; Miree, C.E. Causation or covariation: An empirical re-examination of the link between TQM and financial performance. J. Oper. Manag. 2004, 22, 291-311. [CrossRef]

108. Iqbal, N.; Ahmad, N.; Basheer, N.A.; Nadeem, M. Impact of corporate social responsibility on financial performance of corporations: Evidence from Pakistan. Int. J. Learn. Dev. 2012, 2, 107-118. [CrossRef]

109. Sadikoglu, E.; Zehir, C. Investigating the effects of innovation and employee performance on the relationship between total quality management practices and firm performance: An empirical study of Turkish firms. Int. J. Prod. Econ. 2010, 127, 13-26. [CrossRef]

110. ASQ. Quality Glosary [WWW Document] [Internet]. 2018. Available online: https://asq.org/quality-resources /quality-glossary/ q (accessed on 12 April 2021).

111. MBNQA. What IS the Malcolm Baldrige National Quality award (MBNQA)? [WWW Document]. [Internet]. 2019. Available online: https:/ / asq.org/qualityresources/malcolm-baldrige-national-quality-award (accessed on 12 April 2021).

112. Ooi, K.-B. TQM: A facilitator to enhance knowledge management? A structural analysis. Expert Syst. Appl. 2014, 41, 5167-5179. [CrossRef]

113. London, C. Strategic planning for business excellence. Qual. Prog. 2002, 35, 26.

114. Oakland, J. Leadership and policy deployment: The backbone of TQM. Total Qual. Manag. Bus. Excell. 2011, 22, 517-534. [CrossRef]

115. Zhang, Z.; Waszink, A.B.; Wijngaard, J. An instrument for measuring TQM implementation for Chinese manufacturing companies. Int. J. Qual. Reliab. Manag. 2000, 17, 730-755. [CrossRef]

116. Rao, S.S.; Solis, L.E.; Raghunathan, T.S. A framework for international quality management research: Development and validation of a measurement instrument. Total Qual. Manag. 1999, 10, 1047-1075. [CrossRef]

117. Crosby, P.B. Quality is Free: The Art of Making Quality Certain; McGraw-hill: New York, NY, USA, 1979 ; Volume 94.

118. Juran, J.M. Juran on Planning for Quality; Juran Institute: New York, NY, USA, 1998.

119. Carroll, A.B. The pyramid of corporate social responsibility: Toward the moral management of organizational stakeholders. Bus. Horiz. 1991, 34, 39-48. [CrossRef]

120. Porter, L.J.; Parker, A.J. Total quality management-the critical success factors. Total Qual. Manag. 1993, 4, 13-22. [CrossRef]

121. EFQM. The EFQM Excellence Model; EFQM Publications: Brussels, Belgium, 2010.

122. Bou-Llusar, J.C.; Escrig-Tena, A.B.; Roca-Puig, V.; Beltrán-Martín, I. An empirical assessment of the EFQM Excellence Model: Evaluation as a TQM framework relative to the MBNQA Model. J. Oper. Manag. 2009, 27, 1-22. [CrossRef]

123. Voegtlin, C.; Greenwood, M. Corporate social responsibility and human resource management: A systematic review and conceptual analysis. Hum. Resour. Manag. Rev. 2016, 26, 181-197. [CrossRef]

124. Dubey, R.; Singh, T.; Ali, S.S. The mediating effect of human resource on successful total quality management implementation. Benchmarking Int. J. 2015, 22, 1453-1480. [CrossRef]

125. Wickramasinghe, V.; Gamage, A. High-involvement work practices, quality results, and the role of HR function. TQM J. 2011, 23, 516-530. [CrossRef]

126. Meyer, S.M.; Collier, D.A. An empirical test of the causal relationships in the Baldrige Health Care Pilot Criteria. J. Oper. Manag. 2001, 19, 403-426. [CrossRef]

127. Shen, J.; Jiuhua Zhu, C. Effects of socially responsible human resource management on employee organizational commitment. Int. J. Hum. Resour. Manag. 2011, 22, 3020-3035. [CrossRef]

128. Kim, Y.; Kim, S.-Y. The influence of cultural values on perceptions of corporate social responsibility: Application of Hofstede's dimensions to Korean public relations practitioners. J. Bus. Ethics 2010, 91, 485-500. [CrossRef]

129. Davies, I.A.; Crane, A. Corporate social responsibility in small-and medium-size enterprises: Investigating employee engagement in fair trade companies. Bus. Ethics A Eur. Rev. 2010, 19, 126-139. [CrossRef] 
130. Brammer, S.; Millington, A.; Rayton, B. The contribution of corporate social responsibility to organizational commitment. Int. J. Hum. Resour. Manag. 2007, 18, 1701-1719. [CrossRef]

131. Nguyen, N.N.H.; Truong, T.P. Regulatory enforcement, financial reporting quality and investment efficiency: A pitch. Account. Res. J. 2017, 30, 12-18. [CrossRef]

132. Luthra, S.; Govindan, K.; Kannan, D.; Mangla, S.K.; Garg, C.P. An integrated framework for sustainable supplier selection and evaluation in supply chains. J. Clean. Prod. 2017, 140, 1686-1698. [CrossRef]

133. Cooke, R.A.; Rousseau, D.M. Behavioral norms and expectations: A quantitative approach to the assessment of organizational culture. Gr. Organ. Stud. 1988, 13, 245-273. [CrossRef]

134. Vestal, K.W.; Fralicx, R.D.; Spreier, S.W. Organizational culture: The critical link between strategy and results. J. Healthc. Manag. $1997,42,339$.

135. Han, S.B.; Chen, S.K.; Ebrahimpour, M. The impact of ISO 9000 on TQM and business performance. J. Bus. Econ. Stud. 2007, 13, 1.

136. Glaser, S.R.; Zamanou, S.; Hacker, K. Measuring and interpreting organizational culture. Manag. Commun. Q. 1987, 1, $173-198$. [CrossRef]

137. Hair Jr, J.F.; Hult, G.T.M.; Ringle, C.; Sarstedt, M. A primer on Partial Least Squares Structural Equation Modeling (PLS-SEM); Sage Publications: Thousand Oaks, CA, USA, 2016.

138. Khalil, M.A.; Khalil, M.K.; Khalil, R. Passive but defiant: The role of innovative capabilities in knowledge management and corporate entrepreneurship. J. Entrep. Emerg. Econ. 2021. [CrossRef]

139. Khalil, M.K.; Khalil, R.; Khan, S. A study on the effect of supply chain management practices on organizational performance with the mediating role of innovation in SMEs. Uncertain. Supply Chain Manag. 2019, 7, 179-190. [CrossRef]

140. Lindell, M.K.; Whitney, D.J. Accounting for common method variance in cross-sectional research designs. J. Appl. Psychol. 2001, 86, 114. [CrossRef]

141. Podsakoff, N.P.; Whiting, S.W.; Welsh, D.T.; Mai, K.M. Surveying for "artifacts": The susceptibility of the OCB-performance evaluation relationship to common rater, item, and measurement context effects. J. Appl. Psychol. 2013, 98, 863. [CrossRef] [PubMed]

142. Henseler, J.; Ringle, C.M.; Sinkovics, R.R. The use of partial least squares path modeling in international marketing. In New Challenges to International Marketing; Emerald Group Publishing Limited: Bingley, West Yorkshire, UK, 2009.

143. Hair, J.F., Jr.; Sarstedt, M.; Hopkins, L.; Kuppelwieser, V.G. Partial least squares structural equation modeling (PLS-SEM). Eur. Bus. Rev. 2014, 26, 106-121. [CrossRef]

144. Campbell, D.T.; Fiske, D.W. Convergent and discriminant validation by the multitrait-multimethod matrix. Psychol. Bull. 1959, 56, 81. [CrossRef]

145. Frost, J. How high should R-squared be in regression analysis. Minitab Blog 2014, 9, 30-39.

146. Cohen, J. Statistical Power Analysis for the Behavioural Sciences, 2nd ed.; L. Erlbaum Associates: Hillsdale, NJ, USA, 1988.

147. Chin, W.W. Commentary: Issues and Opinion on Structural Equation Modeling; Management Information Systems Research Center, University of Minnesota: Minneapolis, MN, USA, 1998.

148. Hu, L.; Bentler, P.M. Fit indices in covariance structure modeling: Sensitivity to underparameterized model misspecification. Psychol. Methods 1998, 3, 424. [CrossRef]

149. Suleman, Q.; Gul, R. Challenges to Successful Total Quality Management Implementation in Public Secondary Schools: A Case Study of Kohat District, Pakistan. J. Educ. Pract. 2015, 6, 123-134.

150. Eniola, A.A.; Olorunleke, G.K.; Akintimehin, O.O.; Ojeka, J.D.; Oyetunji, B. The impact of organizational culture on total quality management in SMEs in Nigeria. Heliyon 2019, 5, e02293. [CrossRef] [PubMed]

151. Baird, K.; Hu, K.J.; Reeve, R. The relationships between organizational culture, total quality management practices and operational performance. Int. J. Oper. Prod. Manag. 2011, 31, 789-814. [CrossRef]

152. Hart, S.L.; Ahuja, G. Does it pay to be green? An empirical examination of the relationship between emission reduction and firm performance. Bus. Strateg. Environ. 1996, 5, 30-37. [CrossRef]

153. Berchicci, L.; King, A. 11 postcards from the edge: A review of the business and environment literature. Acad. Manag. Ann. 2007, 1, 513-547. [CrossRef]

154. Afum, E.; Osei-Ahenkan, V.Y.; Agyabeng-Mensah, Y.; Owusu, J.A.; Kusi, L.Y.; Ankomah, J. Green manufacturing practices and sustainable performance among Ghanaian manufacturing SMEs: The explanatory link of green supply chain integration. Manag. Environ. Qual. Int. J. 2020, 31, 1457-1475. [CrossRef] 